NBER WORKING PAPER SERIES

\title{
MEASURING BILATERAL EXPORTS OF VALUE ADDED: A UNIFIED FRAMEWORK
}

\author{
Bart Los \\ Marcel P. Timmer \\ Working Paper 24896 \\ http://www.nber.org/papers/w24896 \\ NATIONAL BUREAU OF ECONOMIC RESEARCH \\ 1050 Massachusetts Avenue \\ Cambridge, MA 02138 \\ August 2018
}

Financial support from the UK Economic Statistics Centre of Excellence (ESCoE) for Bart Los and from the Dutch Science Foundation (NWO) for Marcel Timmer (grant number 453-14-012) is gratefully acknowledged. The authors thank Wen Chen for research assistance. They also thank Robert Johnson, Helena Loiola and participants at the NBER-CRIW Conference on The Challenges of Globalization in the Measurement of National Accounts, (9-10 March 2018, Washington DC, USA) and the 26th International Input-Output Conference (25-29 June 2018, Juiz de Fora, Brazil) for useful comments. The views expressed herein are those of the authors and do not necessarily reflect the views of the National Bureau of Economic Research.

NBER working papers are circulated for discussion and comment purposes. They have not been peer-reviewed or been subject to the review by the NBER Board of Directors that accompanies official NBER publications.

(C) 2018 by Bart Los and Marcel P. Timmer. All rights reserved. Short sections of text, not to exceed two paragraphs, may be quoted without explicit permission provided that full credit, including $(\odot$ notice, is given to the source. 
Measuring Bilateral Exports of Value Added: A Unified Framework

Bart Los and Marcel P. Timmer

NBER Working Paper No. 24896

August 2018

JEL No. F1

\begin{abstract}
$\underline{\text { ABSTRACT }}$
We provide a unified framework for measuring bilateral exports of value added. We outline a general methodology that encompasses the measures introduced by Johnson and Noguera (2012) (value added consumed abroad) and Los et al. (2016) (value added in exports), to which we refer as VAX-C and VAX-D, respectively. In addition we suggest a novel third measure, VAX-P, which indicates the value added used abroad in the final stage of production. We show that they can all be derived with the method of hypothetical extraction in a general input-output model. This is helpful in comparing and contrasting their characteristics. As a corollary, we show that for VAX-C and VAX-P the sum of bilateral measures is equal to the corresponding aggregate measure, but that this is generally not true for VAX-D. We illustrate all measures with empirical examples computed on the basis of the World Input-Output Database. These indicators can found at www.wiod.org.
\end{abstract}

Bart Los

University of Groningen

Faculty of Economics and Business

Groningen Growth and Development Centre

9700 AV Groningen

The Netherlands

b.los@rug.nl

Marcel P. Timmer

University of Groningen

Faculty of Economics and Business

Groningen Growth and Development Centre

The Netherlands

m.p.timmer@rug.nl

A Full set of indicators (2000-2014) is available at http://www.wiod.org/gvc\#nber 


\section{Introduction}

Which countries are most important in demanding value added of a country? This is a pressing question for policy-makers seeking for example to (re)negotiate trade agreements or assessing the domestic consequences of foreign demand shocks. If trade in intermediate products would be absent, the answer to this question would be simple and could be derived from bilateral gross export statistics. However, with international fragmentation of production processes, trade flows need to be measured in value added terms as countries will be exporting and importing intermediates (Hummels et al., 2001). ${ }^{1}$ The main aim of this paper to offer an integrated discussion on measures of value added in bilateral trade flows. We provide a unified framework based on an application of the hypothetical extraction method in global input-output tables, along the lines of Los et al. (2016). We believe that this is helpful in cleaning up terminology, standardizing concepts and more generally providing clear guidelines which measure to use for what type of questions.

In particular, we show that the bilateral trade measures introduced by Johnson and Noguera (2012) (value added consumed abroad) and Los et al. (2016) (value added in exports) are special cases of a general class of VAX measures. We will therefore refer to these as VAX-C and VAX$\mathrm{D}$, respectively. In addition we suggest a novel third measure, VAX-P, which indicates the value added used abroad in the final stage of production. This is another relevant measure as it is at this final stage where demand shocks are transmitted to production and associated intermediates trade flows, as in Bems et al. (2011, 2013). As for VAX-C, there can be flows of VAX-P between pairs of countries that do not directly trade with each other.

We show that all VAX measures can be derived with the method of hypothetical extraction in a general input-output model. In addition, the framework will also help to elucidate the relationship between aggregate and bilateral measures. ${ }^{2}$ This is important as currently there are two alternative definitions of bilateral VAX-D: one suggested by Los et al. (2016) and another

\footnotetext{
${ }^{1}$ Trade in value added measurement has quickly expanded and broadened into a wider set of so-called global value chain (GVC) measures. See Johnson (2017) for a general overview. By now, these statistics are part of the toolkit for trade policy analysis. For example, they are published on a regular basis by the OECD/WTO Trade in value added (TiVA) initiative and in the WITS (World Integrated Trade Solution) database.

${ }^{2}$ We use the term "aggregate exports" to refer to the total exports of a country, irrespective of the partner country. This is to be distinguished from "bilateral exports" that are for a specific destination.
} 
by Wang et al. (2018). We will argue that the first is more suitable for trade analysis as it does not impose that the sum of VAX-D to all destinations is equal to VAX-D in aggregate exports. We show that the difference is small empirically (at current levels of international fragmentation of production processes), but outline the fundamental conceptual difference which potentially can cause major confusion for users.

The remainder of the paper is organized as follows. We will lay out concepts and terminology through some simple examples in section 2. This is to develop intuition. The actual computational formulas are given in section 3. Empirical examples for a few large countries based on data from the World Input-Output Database are discussed in section $4 .{ }^{3}$ Section 5 defends our choice for a bilateral VAX-D measure. Section 6 concludes.

\section{Concepts and terminology}

In this section we will lay out our concepts and terminology, and illustrate these with an example of a simple sequential production chain (a "snake"). The general insights do not depend on the example however and as shown algebraically in section 3 they are generally applicable in any constellation of the production network. ${ }^{4}$

Figure 1 depicts a simple production process in which there are four stages of production, each taking place in a different country. We opt for the most simple constellation through which we can still illustrate our concepts. Country Z produces an intermediate input (from scratch), used by country $\mathrm{R}$ to produce intermediates, which are subsequently used by country $\mathrm{S}$ to produce an intermediate for country $\mathrm{T}$. Country $\mathrm{T}$ is what we call the country-of-completion. This is the country where the final stage of production takes place. Country $U$ is importing the final good from Country $\mathrm{T}$ and consumes it. ${ }^{5}$ In each stage of production 1 unit of value is added to the product, such that the price paid for the final product is 4 .

\footnotetext{
${ }^{3}$ A full annual time series (2000-2014) of bilateral measures for 43 countries has been made available to the research community, via www.wiod.org/gvc\#nber.

${ }^{4}$ It can consist of snakes, spiders or any combination of these (see Baldwin and Venables, 2013, for a discussion of the differences).

${ }^{5}$ Throughout the paper we will refer to consumption, for ease of exposition. In the empirical analysis, we consider final use, which does not only include household and government consumption, but also private and public gross fixed capital formation and changes in inventories.
} 
In Figure 2 we show the input-output table that corresponds to this production chain. The intermediate use block has the very simple structure of a sequential production chain. ${ }^{6}$ Note that gross output of each product (in the bottom row) is equal to its total use (indicated in the last column) as required to have a closed system such that use is equal to supply for all products. ${ }^{7}$ In the next section, we will use this IO-table to discuss the complications arising from "loops".

Figure 1 Example of sequential production chain

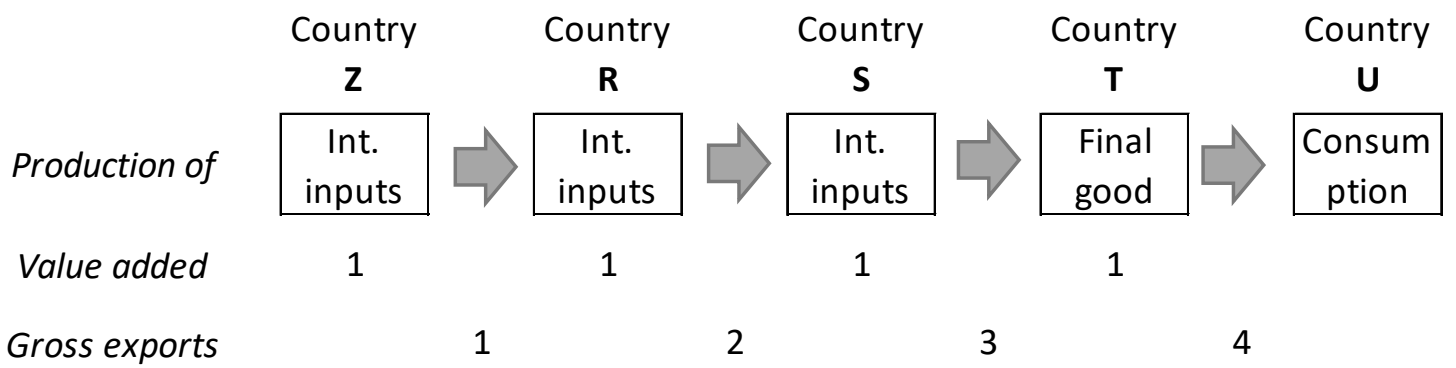

Figure 2 Input-output table corresponding to Figure 1

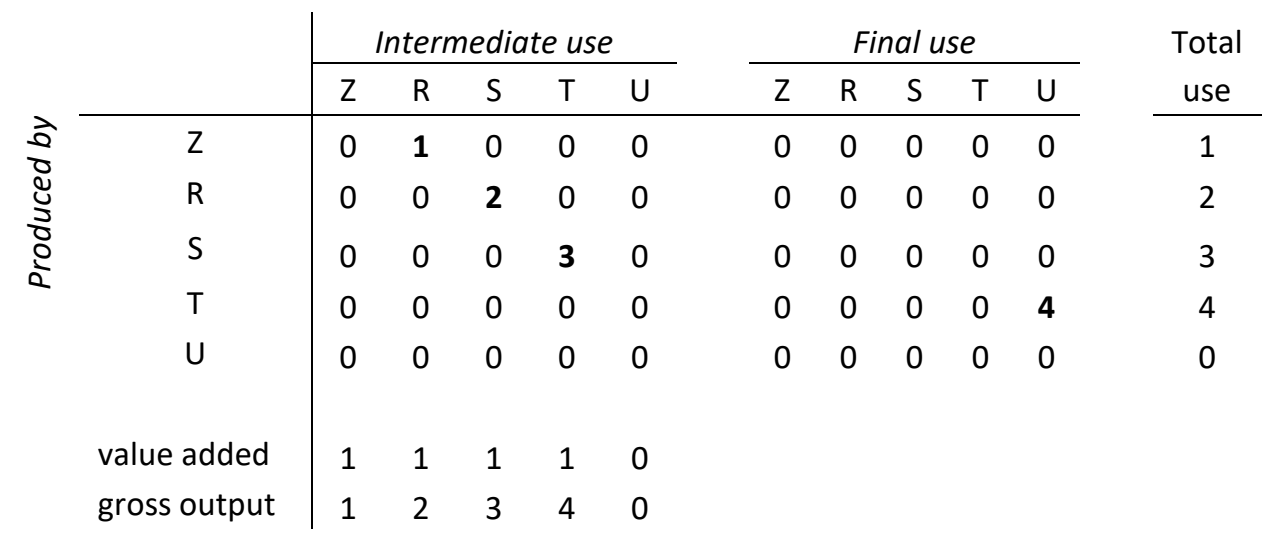

With this set-up we next introduce the family of bilateral export measures. These are shown in Table 1. We only report on those country pairs for which there is a non-zero export flow for at least one of the measures (so we do not report e.g. on bilateral exports from $U$ to any other

\footnotetext{
${ }^{6}$ More formally, a snake is a production chain that can be represented (with suitable permutation) in the intermediate use matrix by a single non-main diagonal of positive transaction values and zeros elsewhere.

${ }^{7}$ The input-output tables presented throughout the paper are expressed in monetary units.
} 
country). We also do not report on Z, as this is not needed for making our main points. The numbers should be clear from the example, and can be checked using the information in Table 1 with the formulas to be presented in section 3. The first row indicates the traditional gross flows. The next rows show three different variants of value added exports (VAX): for direct use (VAX-D), for final stage production (VAX-P) and for consumption (VAX-C).

Table 1 Measures of bilateral exports

\begin{tabular}{|c|c|c|c|c|c|c|}
\hline & \multicolumn{3}{|c|}{ From $\mathrm{R}$ to } & \multicolumn{2}{|c|}{ From $\mathrm{S}$ to } & \multirow{2}{*}{$\begin{array}{c}\text { From } \mathrm{T} \text { to } \\
\mathrm{U}\end{array}$} \\
\hline & $\mathrm{S}$ & $\mathrm{T}$ & $\mathrm{U}$ & $\mathrm{T}$ & $\mathrm{U}$ & \\
\hline Gross exports & 2 & 0 & 0 & 3 & 0 & 4 \\
\hline \multicolumn{7}{|l|}{ Domestic value added exports (VAX) } \\
\hline for direct use (VAX-D) & 1 & 0 & 0 & 1 & 0 & 1 \\
\hline for final stage production (VAX-P) & 0 & 1 & 0 & 1 & 0 & 0 \\
\hline for consumption (VAX-C) & 0 & 0 & 1 & 0 & 1 & 1 \\
\hline
\end{tabular}

Note: based on Figure 1

Various alternative indices of bilateral VAX-D have been suggested, e.g. by Hummels et al. (2001), Los et al. (2016) and Wang et al. (2018). We prefer to use the one suggested by Los et al. (2016) as will be explained in Section 5. VAX-D is equal to gross exports when all activities needed to produce the exported good are performed within the exporting country. The share of VAX-D in gross exports is declining in the amount of intermediates imported by the country in any domestic stage of production. For R, the share of VAX-D in gross exports is 0.5. Note that VAX-D includes value added in the export of intermediates (as in exports from $\mathrm{S}$ to $\mathrm{T}$ ) as well as of final goods (as in exports from $\mathrm{T}$ to $\mathrm{U}$ ).

Johnson and Noguera (2012) introduced the concept of VAX-C at both the aggregate and bilateral level. Johnson (2014) provides an overview of stylised facts. It is defined as the value added that is generated in a country but consumed abroad. ${ }^{8}$ We refer to it as VAX-C. Unlike VAX-C, VAX-D includes all value added that crosses the border, irrespective of where it is ultimately consumed. Considered for the aggregate set of other countries, it is therefore always at least as large as VAX-C, and strictly larger if some VAX-D is consumed domestically (as

\footnotetext{
${ }^{8}$ Johnson and Noguera $(2012,2017)$ refer to it as "value added absorbed abroad". In the context of VAX-P and VAX-C, "absorbed by" is ambiguous (as it could be absorbed in the final product, or by the consumer) and we therefore use the term "consumed abroad" instead.
} 
shown in Koopman et al., 2014). This is not true when considering bilateral flows, however. It is here that the conceptual difference between VAX-D and VAX-C is most visible. There can be a bilateral flow of VAX-C between a pair of countries without a direct flow of exports, as in the case of $\mathrm{R}$ to $\mathrm{U}$, or $\mathrm{S}$ to $\mathrm{U}$, as indicated in Table 1 .

This characteristic of VAX-C has major implications for its use in trade analysis. VAX-C is a popular measure and used for example by Aichele et al. (2014), Johnson and Noguera (2017), Kaplan et al. (2018) and Brakman et al. (2018) in studies of the effects of trade agreements. They relate bilateral VAX-C flows to trade agreements between the two countries involved, using a gravity equation framework. Using trade flows in value added terms rather than gross exports is needed indeed. Yet, such analyses should ideally be based on VAX-D rather than VAX-C flows. ${ }^{9}$ This can be explained by referring to the stylized production chain in Figure 1. A reduction of trade barriers between $\mathrm{R}$ and $\mathrm{S}$ is commonly supposed to have positive effects on the bilateral value added exports between these two countries, which is captured by VAXD. The effects of a trade agreement between $R$ and $U$ are less obvious, however. Such an agreement will not reduce trade barriers at borders that are crossed by R's exported value added, which are the borders between $\mathrm{R}$ and $\mathrm{S}$, between $\mathrm{S}$ and $\mathrm{T}$ and between $\mathrm{T}$ and $\mathrm{U}$. The first order effect of a trade agreement between $R$ and $U$ on the value added exported from $R$ to $U$ is therefore expected to be nil. Trade barriers at other borders are likely to be much more relevant and should be modeled as well in the gravity setup, even when one is only interested in the effects of trade agreements on VAX-C. ${ }^{10}$

We introduce a third measure of VAX, namely VAX for final stage production (VAX-P). It is the domestic value added in exports that is used abroad in the production of a final good. This is another relevant measure as it is at this final stage where consumption and investment demand shocks for specific products are transmitted to production and associated intermediates trade flows, as in Bems et al. (2011, 2013), who studied the causes of the global trade collapse in 2008-2009. There might also be idiosyncratic shocks to the final-stage country, which will percolate to its trading partners further up the chain. Blanchard et al. (2017), for example,

\footnotetext{
${ }^{9}$ This might not be surprising, given the fact that VAX-C was the only value added based trade measure defined at the bilateral level for quite a while. More recently, Dhingra et al. (2018) and Laget et al. (2018) studied trade policies using VAX-D measures. Unfortunately, they use the measure proposed by Wang et al. (2018), about which we argue that it has an undesirable property (see section 5).

${ }^{10}$ This point is also made in Noguera (2012).
} 
analyze the relationships between tariffs on final products sold by specific countries and the origins of value added contained in these.

As a final comment, it should be noted that in principle an unlimited number of related measures could be introduced, only bounded by the number of stages in the chain. We view VAX-P as the most relevant however (in addition to VAX-D and VAX-C), as it clearly delineates between trade in intermediate and in final products. After this stage there is only trade in final goods, and before this stage there is only trade in intermediates in the chain. As for VAX-C, there can be flows of VAX-P between a pair of countries without a flow of direct exports, as from R to T.

\section{A unified framework for bilateral value added export measures}

\section{3a. Preliminaries and notation}

In this section, we show how the three indicators of bilateral exports of domestic value added can be computed if a global input-output table is available. The general structure of such a table is given by Figure 3 .

Figure 3: The structure of a global input-output table

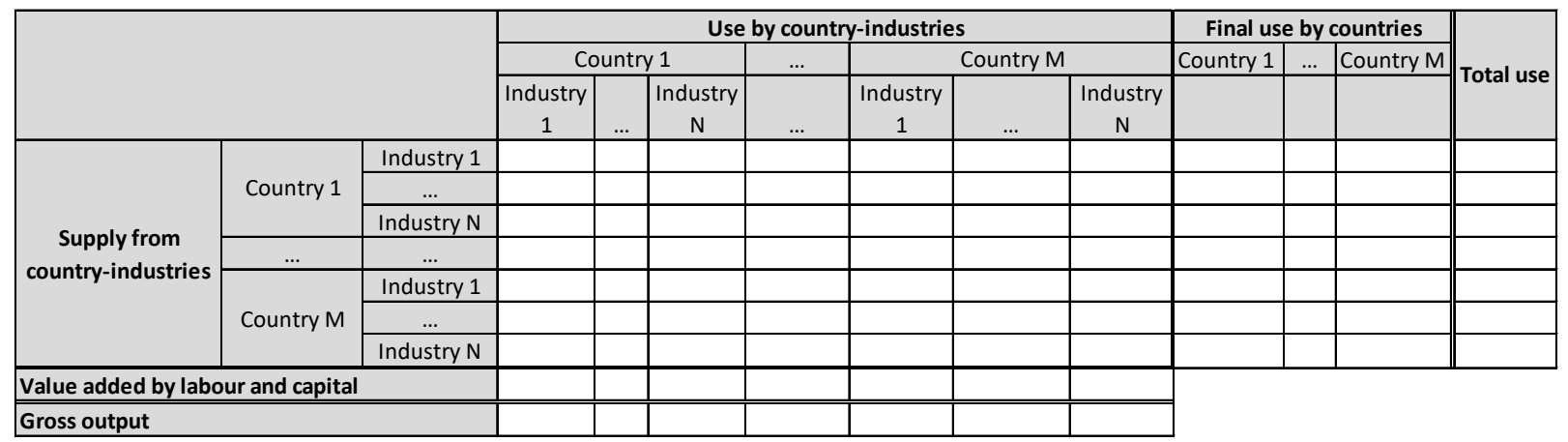

Notes: Global IO tables do not have country detail for all countries in the world. Hence, Country M often refers to a region labeled "Rest of the World".

Source:Timmer et al. (2015).

In what follows, we will assume that the countries in a global input-output table can be grouped into three groups: (i) the country (or group of countries) for which we want to compute VAXindicators, indicated by $r$; (ii) the country (or group of countries) that acts as the destination of the VAX, indicated by $s$; and (iii) the other countries in the world, indicated by $t$. In matrix 
notation, the input-output structure of Figure 3 can in this context be represented by a limited number of matrices and vectors: ${ }^{11}$

$\mathbf{Z} \equiv\left[\begin{array}{lll}\mathbf{Z}_{r r} & \mathbf{Z}_{r s} & \mathbf{Z}_{r t} \\ \mathbf{Z}_{s r} & \mathbf{Z}_{s s} & \mathbf{Z}_{s t} \\ \mathbf{Z}_{t r} & \mathbf{Z}_{t s} & \mathbf{Z}_{t t}\end{array}\right] ; \quad \mathbf{Y} \equiv\left[\begin{array}{ccc}\mathbf{Y}_{r r} & \mathbf{Y}_{r s} & \mathbf{Y}_{r t} \\ \mathbf{Y}_{s r} & \mathbf{Y}_{s s} & \mathbf{Y}_{s t} \\ \mathbf{Y}_{t r} & \mathbf{Y}_{t s} & \mathbf{Y}_{t t}\end{array}\right] ; \quad \mathbf{w} \equiv\left[\begin{array}{c}\mathbf{w}_{r} \\ \mathbf{w}_{s} \\ \mathbf{w}_{t}\end{array}\right] ; \quad \mathbf{x} \equiv\left[\begin{array}{c}\mathbf{x}_{r} \\ \mathbf{x}_{s} \\ \mathbf{x}_{t}\end{array}\right]$

There are $M$ countries, each with $N$ industries. $\mathbf{Z}$ is the $N M x N M$ matrix of which the elements indicate the transaction values of sales among industries in the accounting period, usually a year. The rows refer to the supplying industries, the columns to using industries. Both transactions within a country (in the diagonal submatrices) and cross-border transactions (in the off-diagonal submatrices) are included in this matrix. It should be noted that the submatrices generally do not have the same dimensions. In order to avoid aggregation biases (Morimoto, 1970), all industry and country detail should be retained in the computations. If $r$ is a single country, $\mathbf{Z}^{r r}$ has $N$ rows and columns. If $s$ is a group of $M_{s}$ countries, $\mathbf{Z}^{s s}$ has $N M_{s}$ rows and columns.

$\mathbf{Y}$ is the rectangular matrix of which the elements give the transaction values of sales by industries to final users. Like in $\mathbf{Z}$, both domestic and international transactions are contained in this matrix. Since we treat all final use categories (household consumption, gross fixed capital formation, etc.) in the same way, $\mathbf{Y}$ contains $M$ columns (one column for each country). Since all industries in all countries can sell to final users, the number of rows is $N M$. The dimensions of the submatrices vary, depending on the numbers of countries included in $r$, $s$ and $t$.

Value added in each of the industries in each country is contained in the $N M$-vector $\mathbf{w}$, and gross output levels in the $N M$-vector $\mathbf{x}$. The well-known input-output identities apply. The sum of intermediate sales and sales to final users (both summed over countries of destination) equals gross output, $\mathbf{x}=\mathbf{Z i}+\mathbf{Y} \mathbf{i}$, in which $\mathbf{i}$ denotes a summation vector (of appropriate length) containing ones; the sum of purchases of intermediate inputs and payments for production factors (value added) also add up to these values, $\mathbf{x}=\mathbf{i}^{\prime} \mathbf{Z}+\mathbf{w}$.

\footnotetext{
${ }^{11}$ Matrices are indicated by bold capitals, column vectors by bold lowercases and scalars by italics. Primes denote transposition and hats stand for diagonal matrices.
} 
The production requirements per unit of output are given by the $N M x N M$ matrix $\mathbf{A}$ (for intermediate inputs) and the $N M$-vector $\mathbf{v}$ (for factor payments):

$\mathbf{A}=\mathbf{Z} \hat{\mathbf{x}}^{-1}=\left[\begin{array}{ccc}\mathbf{A}_{r r} & \mathbf{A}_{r s} & \mathbf{A}_{r t} \\ \mathbf{A}_{s r} & \mathbf{A}_{s s} & \mathbf{A}_{s t} \\ \mathbf{A}_{t r} & \mathbf{A}_{t s} & \mathbf{A}_{t t}\end{array}\right] ; \quad \mathbf{v}=\hat{\mathbf{x}}^{-1} \mathbf{w} \equiv\left[\begin{array}{c}\mathbf{v}_{r} \\ \mathbf{v}_{s} \\ \mathbf{v}_{t}\end{array}\right]$

Country r's GDP can now be obtained by linking value added generation to the final demand levels in $\mathbf{Y}$ by means of Leontief's demand-driven input-output model:

$G D P_{r}=\tilde{\mathbf{v}}_{r}^{\prime}(\mathbf{I}-\mathbf{A})^{-1} \mathbf{Y i}$

in which $\widetilde{\mathbf{v}}_{r}$ denotes the $N M$-vector that is identical to $\mathbf{v}$ as defined in (1) with respect to the part $\mathbf{v}_{r}$, but in which all other elements are set equal to zero. ${ }^{12}$ The matrix $(\mathbf{I}-\mathbf{A})^{-1}$ is known as the "Leontief inverse”. It explicitly takes into account that the industry that is producing the final product often does not only use its own production factors, but also intermediate inputs from first-tier suppliers. These can be located in the same country, but also elsewhere. First-tier suppliers generate value added themselves, but might also use intermediate inputs for their activities. The same goes for second-tier suppliers producing these, and so on. ${ }^{13}$

In their comment on Koopman et al. (2014), Los et al. (2016) showed that using a particular type of the "Hypothetical Extraction Method" (HEM) as pioneered by Paelinck et al. (1965) and Strassert (1968) can be used to derive VAX-D. ${ }^{14}$ The main part of Los et al. (2016) dealt with the aggregate case, in which domestic value added in the exports of country $r$ to all other countries is considered at once. They also proposed a bilateral extension, to which we will turn now.

3b. The hypothetical extraction method (HEM)

HEM-applications usually "extract” industries or countries from input-output structures by setting corresponding parts of matrices that are involved in the computations to zero. Equation (2) is then recomputed for the modified matrices: the result is called the hypothetical GDP level.

\footnotetext{
${ }^{12}$ If the vector $\mathbf{v}$ would be used instead, we would obtain world GDP rather than GDP of $r$.

${ }^{13}$ See, e.g., the appendix of Los et al. (2015) for a more extensive exposition.

${ }^{14}$ See Miller and Lahr (2001) for a comprehensive overview of HEM-based input-output analyses, and Dietzenbacher et al. (1993) for an application involving multiple countries.
} 
The difference between the actual and the hypothetical GDP levels is a measure of the importance of the extracted industry. In computing VAX-D, we do not extract entire industries (or countries) from the system, but just some transactions. If we are interested in VAX-D between $r$ and $s$, we set all elements of $\mathbf{A}_{r s}$ and $\mathbf{Y}_{r s}$ to zero, assuming that $s$ does not use any imports of intermediate and final products from $r$. One might think of this as a situation in which $s$ sets import tariffs on goods from $r$ that are prohibitively high. We indicate the modified matrices with a *:

$\mathbf{A}_{r}^{* s} \equiv\left[\begin{array}{ccc}\mathbf{A}_{r r} & \mathbf{0} & \mathbf{A}_{r t} \\ \mathbf{A}_{s r} & \mathbf{A}_{s s} & \mathbf{A}_{s t} \\ \mathbf{A}_{t r} & \mathbf{A}_{t s} & \mathbf{A}_{t t}\end{array}\right] ; \quad \mathbf{Y}_{r}^{* s} \equiv\left[\begin{array}{ccc}\mathbf{Y}_{r r} & \mathbf{0} & \mathbf{Y}_{r t} \\ \mathbf{Y}_{s r} & \mathbf{Y}_{s s} & \mathbf{Y}_{s t} \\ \mathbf{Y}_{t r} & \mathbf{Y}_{t s} & \mathbf{Y}_{t t}\end{array}\right]$

Next, we compute the GDP level in $r$ for the situation in which these matrices would have represented the global production structure and final demand levels:

$G D P_{r}^{* s}=\tilde{\mathbf{v}}_{r}^{\prime}\left(\mathbf{I}-\mathbf{A}_{r}^{* s}\right)^{-1} \mathbf{Y}_{r}^{* s} \mathbf{i}$

The value added of $r$ contained in direct exports to $s$ is now given by the difference between $r$ 's actual GDP level and its hypothetical GDP level:

$V A X D_{r s}=G D P_{r}-G D P_{r}^{* S}$

We would like to emphasize that $G D P_{r}^{* s}$ should not be seen as the GDP level that would result if exports to $s$ would be prohibitive. In a general setting with more flexible production and demand functions, substitution effects will occur. As a consequence, the global production structure and final demand levels will change and the global production structure after the tariff shock will not be represented by $\mathbf{A}_{r}^{* s}$ and $\mathbf{Y}_{r}^{* s}$.VAX $D_{r s}$ should therefore be regarded as an upper limit to the loss in $G D P_{r}$ and is most meaningful if compared to other scenarios of extracted transactions. Put otherwise, it is a measure of the relative importance of country $s$ for exports of value added by $r{ }^{15}$

\footnotetext{
${ }^{15}$ See, for example, Chen et al. (2018), who measure regional GDP-shares "at risk" to Brexit using this HEM-approach, but argue that substitution effects will most probably lead to smaller actual GDP losses.
} 
We now show how VAX-P can be computed in a similar framework by setting elements of one or more matrices in (2) to zero (see below for a simpler computational formula). VAX-P is the amount of value added used abroad for final production. If we hypothetically extract all final demand for output produced by industries in country $s$, we have

$\mathbf{Y}_{r}^{\# s} \equiv\left[\begin{array}{ccc}\mathbf{Y}_{r r} & \mathbf{Y}_{r s} & \mathbf{Y}_{r t} \\ \mathbf{0} & \mathbf{0} & \mathbf{0} \\ \mathbf{Y}_{t r} & \mathbf{Y}_{t s} & \mathbf{Y}_{t t}\end{array}\right]$

and hypothetical GDP in $r$ is given by

$G D P_{r}^{\# s}=\tilde{\mathbf{v}}_{r}^{\prime}(\mathbf{I}-\mathbf{A})^{-1} \mathbf{Y}_{r}^{\# s} \mathbf{i}$

For VAX-P, we now have the expression

$V A X P_{r s}=G D P_{r}-G D P_{r}^{\# s}$

Johnson and Noguera's (2012) VAX-C indicator can also easily be considered within this HEM-approach (see below for a simpler computational formula for VAX-C). If we hypothetically extract all demand by final users in country $s$, we have

$\mathbf{Y}_{r}^{\& s} \equiv\left[\begin{array}{lll}\mathbf{Y}_{r r} & \mathbf{0} & \mathbf{Y}_{r t} \\ \mathbf{Y}_{s r} & \mathbf{0} & \mathbf{Y}_{s t} \\ \mathbf{Y}_{t r} & \mathbf{0} & \mathbf{Y}_{t t}\end{array}\right]$

The hypothetical GDP-level associated with this extraction reads

$G D P_{r}^{\& s}=\tilde{\mathbf{v}}_{r}^{\prime}(\mathbf{I}-\mathbf{A})^{-1} \mathbf{Y}_{r}^{\& s} \mathbf{i}$

and we obtain the following expression for VAX-C:

$V A X C_{r s}=G D P_{r}-G D P_{r}^{\& s}$

This completes the discussion of the unified framework in which the three measures of bilateral exports of value added can be presented. The aggregate indicator of VAX-D can be computed 
by means of slightly modified versions of (3), (4) and (5). $\mathbf{A}_{r}^{* s t}$ and $\mathbf{Y}_{r}^{* s t}$ are obtained by simultaneously setting $\mathbf{A}_{r s}, \mathbf{A}_{r t}, \mathbf{Y}_{r s}$ and $\mathbf{Y}_{r t}$ equal to zero, after which they are substituted for $\mathbf{A}_{r}^{* s}$ and $\mathbf{Y}_{r}^{* s}$ in (4). The result $\left(G D P_{r}^{* s t}\right)$ is then subtracted from actual GDP, as in (5). The aggregate counterpart of VAX-P is computed by not only setting the row associated with final demand for output from country $s$ but also the row for output from country $t$ equal to zero in (6). Finally, setting both columns for consumption in $s$ and in $t$ in (9) to zero, (10) and (11) yield the aggregate VAX-C.

\section{3c. Simplified expressions for calculation of VAX}

So far, we derived VAX measures using the HEM approach. We did this to stress the relationships between the three VAX indicators. Yet, VAX-P and VAX-C can also be computed in a simpler way given the fact that it only involves the tracing of parts of the final demand matrix. Following the exposition by Los et al. (2015), VAX-P from $r$ to $s$ can be expressed as a simple multiplication with demand for products finalized in s (by any country in the world, including $r$ ):

$V A X P_{r s}=\tilde{\mathbf{v}}_{r}^{\prime}(\mathbf{I}-\mathbf{A})^{-1}\left[\begin{array}{lll}\mathbf{Y}_{s r} & \mathbf{Y}_{s s} & \mathbf{Y}_{s t}\end{array}\right] \mathbf{i}$

Likewise, Johnson and Noguera's (2012) bilateral VAX-C from r to s is usually written as:

$V A X C_{r s}=\tilde{\mathbf{v}}_{r}^{\prime}(\mathbf{I}-\mathbf{A})^{-1}\left[\begin{array}{c}\mathbf{Y}_{r s} \\ \mathbf{Y}_{s S} \\ \mathbf{Y}_{t s}\end{array}\right]$

involving only the demand of $s$ for products finalized in any country, including country $r$ itself.

\section{Empirical Illustrations}

In this section we provide some empirical illustrations of the measures we introduced using the 2016 release of the World Input-Output Database (Timmer et al., 2015). We study the VAX of some major countries in the world (China, Japan, Germany, United Kingdom and United States) 
as well as some global suppliers of raw materials (Australia and Brazil). ${ }^{16}$ We show that bilateral measures can vary widely across the various measures and provide some intuitive interpretation. All results are for the year 2014 and values are expressed in million US\$. For background, we first provide a comparison of aggregate measures of GX, VAX-D, VAX-P and VAX-C in Table 2. Tables A1 to A7 provide for each country the bilateral GX and VAX flows to each of the 42 partner countries (and the rest-of-the-world region), the share of each partner in total flows as well as the ranking based on these shares. We highlight some interesting results.

Table 2 Various aggregate VAX measures, 2014

\begin{tabular}{lccc}
\hline & VAX-D / & VAX-C / & VAX-P / \\
& GX & VAX-D & VAX-D \\
\hline China & $82.4 \%$ & $96.3 \%$ & $47.1 \%$ \\
United States & $87.0 \%$ & $92.1 \%$ & $61.1 \%$ \\
Germany & $70.2 \%$ & $95.4 \%$ & $53.8 \%$ \\
Japan & $74.7 \%$ & $98.4 \%$ & $56.8 \%$ \\
United Kingdom & $77.4 \%$ & $97.9 \%$ & $63.1 \%$ \\
Australia & $83.9 \%$ & $99.1 \%$ & $83.7 \%$ \\
Brazil & $77.1 \%$ & $99.4 \%$ & $74.6 \%$ \\
\hline Note: Authors' calculations based on WIOD, 2016 release.
\end{tabular}

\section{VAX-D compared to $G X$}

Column 1 in Table 2 confirms the finding of Koopman et al. (2014) that aggregate VAX-D is smaller than gross exports (GX). Ratios vary from 70 per cent for Germany to 87 per cent for the US, reflecting the difference in the import content of their exports as stressed by Hummels et al. (2001). As argued by Koopman et al. (2012), these ratios are likely to be overestimations if firm heterogeneity is such that more export-intensive firms have lower VAX-D ratios. They showed that this was the case for China, using data that distinguishes between processing exports and other firms. ${ }^{17}$

Appendix Tables A1 through A7 provide information on the bilateral VAX-D values. In general, the rankings of export destinations are similar for the gross exports and the VAX-D measures. This is not surprising given the nature of the available data. Information on input requirements generally does not vary across export partners. As a consequence, the representation of production technologies of exporting industries is not destination-specific,

\footnotetext{
${ }^{16}$ The measures for all 43 countries included in the 2016 release of WIOD have been made available at the WIOD website (www.wiod.org/gvc\#nber).

${ }^{17}$ The OECD Trade in Value Added database makes this distinction for China and Mexico.
} 
and the WIOD data are no exception. Hence, the VAX-D to GX ratio for a given product is the same across all partners. The variation in results across bilateral partners thus comes from variation in the product mixes of exports bundles towards the various destinations. For example, Canada and Mexico become less important as export partners for the US in terms of VAX-D compared to gross exports. This is because the US exports to these countries is skewed towards products with a low VAX-D ratio. On the other hand, China becomes more important for Brazil as an export destination in terms of VAX-D, because Brazilian exports to China mainly consist of raw materials which have a very high VAX-D ratio.

\section{$V A X$-C compared to VAX-D}

VAX-D includes all value added that crosses the border, irrespective of where it is ultimately consumed. From an aggregate perspective, it is therefore always at least as large as VAX-C as VAX-C only considers value added that is also ultimately consumed abroad (Johnson and Noguera, 2012). Koopman et al. (2014) showed that the empirical differences are small, and we confirm this in the second column of Table 2. This is not true when considering bilateral flows, however, and it is here that the conceptual and empirical differences are clearly visible. First of all, bilateral VAX-C can be higher than GX, and we find many examples of this, in particular in exports towards major consumer markets such as China, Japan and United States. Countries export directly towards these destinations, but also indirectly through other countries (as also found by Johnson and Noguera, 2012).

Second, for individual countries, the importance of various destinations do change compared to VAX-D. For example, South Korea and Taiwan are less important for Japan as consumers of its value added than as direct export markets, while the US is more important as a consumer than as a direct export destination. Similarly, Canada and Mexico are less important for the US, and continental Europe is less important for Germany as consumers than as direct export destination. These findings confirm the well-documented existence of regional production networks (see, e.g. Los et al., 2015).

\section{VAX-P compared to VAX-D}

The last column of Table 2 provides a comparison of aggregate VAX-P with VAX-D. It reveals interesting variation across countries. VAX-P must be lower than VAX-D by definition as it only captures exports of value added that are used in final production abroad. Hence VAX-P will not include exports of final goods and the ratio of VAX-P to VAX-D will thus be mainly influenced by the share of intermediate products (including natural resources) in a country's 
exports. Not surprisingly, the ratio varies from 47 per cent for China, which exports relatively little intermediates, to as much as 84 per cent for Australia, which mainly exports primary intermediates.

The bilateral measures shown in the Appendix tables reveal additional patterns. The share of VAX-P going to China is typically (much) higher than the share of VAX-D or VAX$\mathrm{C}$ going to this country, confirming its important role as a final assembler using intermediates produced elsewhere. For example, 15.3 per cent of direct VAX from Japan goes to China, yet 19.6 per cent of VAX-P. Similarly, 5.7 percent of US VAX-D goes to China, while 8.1 per cent of VAX-P. Interestingly, Chinese VAX-P goes more to less advanced countries (such as India, Indonesia and Mexico) and South Korea (relative to VAX-D or VAX-C shares). Yet the US and Japan are still the largest receivers of Chinese VAX-P.

\section{Which bilateral VAX-D measure to use?}

The aggregate concept of value added exports for direct use (VAX-D) has been introduced by Hummels et al. (2001) and Koopman et al. (2012), and there is unanimous agreement on how to measure it. ${ }^{18}$ This is not true for the bilateral VAX-D measure. Various alternative indices have been suggested including those by Hummels et al. (2001), Los et al. (2016) and Wang et al. (2018). We prefer to use the one suggested by Los et al. (2016) because it is the only one which allows for a situation in which the sum of the bilateral measures across all destinations is not equal to the aggregate measure. This is so in cases in which an exporting country is involved in a specific type of "feedback loop" (Miller, 1966). This situation arises if a country is importing its own value added (embodied in intermediate inputs) from one country to produce its exports to another country. ${ }^{19}$

An example is easily created by replacing country T in Figure 1 by country R, see Figure 4. In this case, $\mathrm{R}$ is importing its own value added that was generated in an earlier stage when producing its exports to $\mathrm{S}$. The corresponding input-output table is shown in Figure 5.

\footnotetext{
${ }^{18}$ In fact, Hummels et al. (2001) suggested the complement to VAX-D: the import content of exports, and referred to it as VS ("vertical specialization"). Koopman et al. (2012) showed that VAX-D is equal to gross exports minus VS (see also Los et al., 2016).

${ }^{19}$ Value added exported to the final stage, or the final consumer, can obviously never be exported by the exporting country again. Hence bilateral VAX always sums to aggregate VAX in the case of VAX$\mathrm{P}$ and VAX-C.
} 
Mathematically, an input-output table has a loop if none of all possible permutation of the intermediate use matrix yields a triangular matrix, defined as a matrix with exclusively zeros below the main diagonal. Such permutations must involve simultaneous changes in the order of the columns and corresponding rows, otherwise the equality of row (use) and column sum (supply) is violated. ${ }^{20}$ In the example of Figure 4, it is clear that there is a loop, as S delivers intermediates to $\mathrm{R}$ and vice versa, hence there is always a positive value below the diagonal block, irrespective of how the countries are ordered in the table.

In Table 3 we report on the bilateral VAX measures, as well as the aggregate (in the columns headed by “All”). Again, we only report on pairs of countries for which there is a non-zero flow for at least one of the VAX measures. The measures for $\mathrm{S}$ are not surprising and basically repeating those for $\mathrm{T}$ in the snake example presented in section 2 (see Table 1). $\mathrm{R}$ is the country of interest. It carries out two stages of production, and exports directly to two countries: $\mathrm{S}$ and U. Its gross exports are 6, while it generates only 2 units of value added in the chain. This is clear from VAX-C: both units are ultimately consumed in $U$ and the sum of the bilateral measures is equal to the aggregate one. This is also true for VAX-P, which in this case is not so insightful as R is the country of completion so VAX-P is zero by definition, for all bilateral pairs as well as in the aggregate sense.

Figure 4 Example of production chain (with loop)

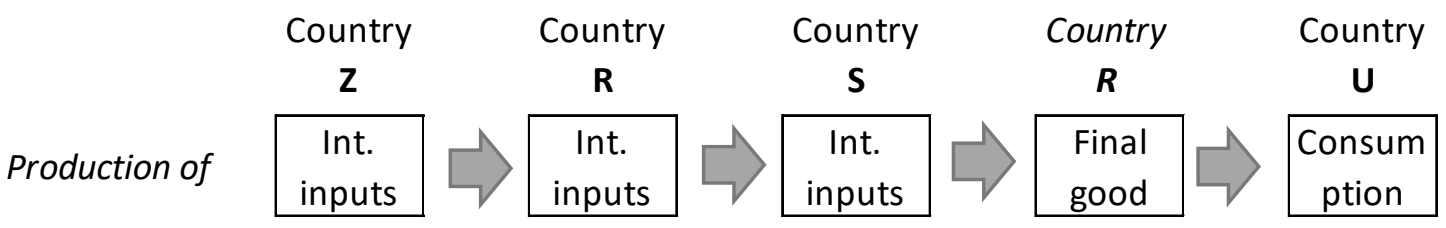

Value added

1

1

1

1

Gross exports

1

2

3

4

\footnotetext{
${ }^{20}$ Chenery and Watanabe (1951) discuss triangularization of input-output matrices in order to make matrix manipulations computationally less cumbersome (which at that time was of course an important topic). Simpson and Tsukui (1956) discuss the economic meaning of (block)triangular input-output tables.
} 
Figure 5 Input-output table corresponding to Figure 4

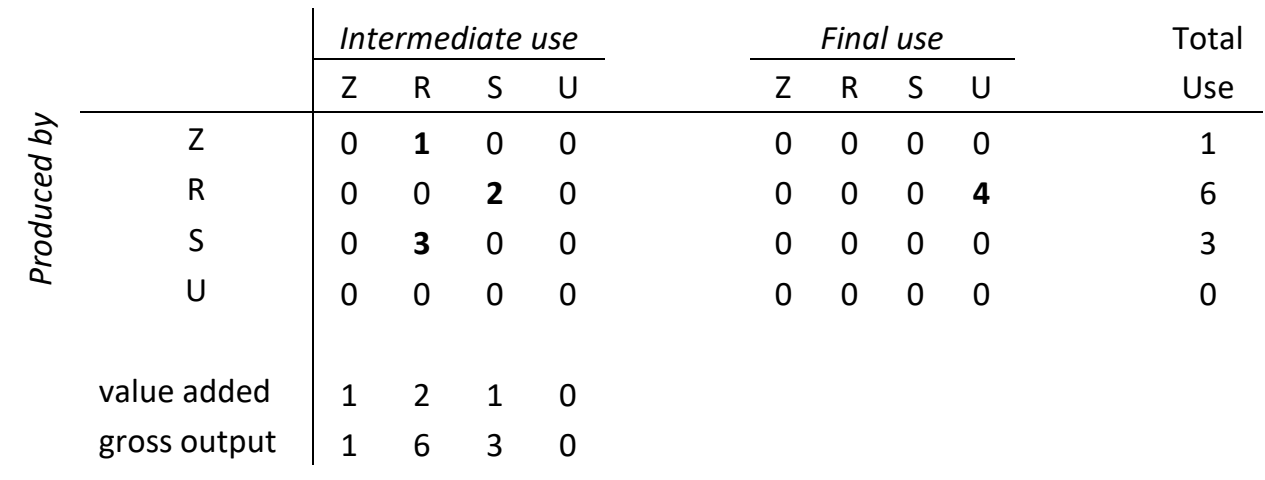

Table 3 Measures of bilateral exports

\begin{tabular}{|c|c|c|c|c|c|c|}
\hline & \multicolumn{3}{|c|}{ From $\mathrm{R}$ to } & \multicolumn{3}{|c|}{ From $\mathrm{S}$ to } \\
\hline & $\mathrm{S}$ & $\mathrm{U}$ & All & $\mathrm{R}$ & $\mathrm{U}$ & All \\
\hline Gross exports & 2 & 4 & 6 & 3 & 0 & 3 \\
\hline Domestic value added exports (VAX) & & & & & & \\
\hline for direct use (VAX-D) & 1 & 2 & 2 & 1 & 0 & 1 \\
\hline for final stage production (VAX-P) & 0 & 0 & 0 & 1 & 0 & 1 \\
\hline for consumption (VAX-C) & 0 & 2 & 2 & 0 & 1 & 1 \\
\hline
\end{tabular}

Note: based on Figure 4

The interesting case arises for VAX-D. R exports 1 unit of value added to S, and R exports 2 units of its value added to $\mathrm{U}$ : the value added in the second stage of the chain and in the fourth stage. Yet, the aggregate VAX-D is also 2 . This is obvious as R adds only 2 units of value added to the chain. We now have a case where the sum of the bilateral measures is higher (3) than the aggregate one (2). The reason is that $\mathrm{R}$ exports the value added it generates in the second stage of the chain twice: first directly to $S$, and again embodied in exports to $U$. We therefore refer to the difference between the sum of the bilateral VAX-Ds and the aggregate VAX-D as the double count of domestic value added in summing bilateral measures.

In a recently revised paper, Wang et al. (2018, WWZ from hereon) provide an alternative measure of bilateral VAX-D, which rules out this type of double counts by design. The authors wish to develop an accounting system in which the overall value added (GDP) of a country is assigned to (bilateral) export flows in a mutually exclusive way. From that perspective, it is only natural to impose an aggregation restriction upfront. But there is a cost involved regarding the measurement of trade relationships. In the WWZ accounting framework, the value added in 
exports from $\mathrm{R}$ to $\mathrm{U}$ would be only 1 unit, not 2. In that way the bilateral measures sum to the aggregate. This might be justified when accounting for GDP, but it is counter-intuitive from a trade perspective. If $\mathrm{U}$ would no longer demand the final good from $\mathrm{R}$, value added in $\mathrm{R}$ will decline by 2 units, as both stages of production are no longer needed. The hypothetical extraction method introduced in the previous section provides a mathematical underpinning for this intuition.

One could argue (as in WWZ) that by tracing the exports and contributions of different industries in a country this double counting would be eliminated. Assume that the first task carried out by R is done in industry R1 (which exports to S), and the second task by industry (which exports to $U$ ). When considering the exports to $U$ one could say that the exports from $R 2$ contain 1 unit of value added by $R 2$. Yet, it remains true that the aggregate exports from $\mathrm{R}$ contain 2 units of R's value added. Having more detailed input-output tables will thus not resolve this as long as one wishes to study aggregate exports of a country, rather than of separate industries in a country.

To be clear, we do not claim that the WWZ decomposition is mathematically "wrong”. As long as the accounting restrictions are obeyed, an accounting framework is correct. But we do claim that the decomposition is essentially arbitrary as one can come up with many alternatives that are equally valid. Without an economic model, it is impossible to defend any choice among these. This point is also made by Nagengast and Stehrer (2016) and they propose to identify the trade flow in which value added is actually recorded for the first time in international trade statistics to allocate value added. Actually, there is a deep and fundamental problem in trying to allocate value added to gross trade flows. Note that the elements in an IO table are summations of transactions within a particular time frame, typically a year. It does not record the sequence of the transactions. This is important to emphasize, because it implies that it is generally impossible to retrieve the underlying production chain, except in very simple cases such as a snake (as stressed by Nomaler and Verspagen, 2014). If loops are present, many different networks can underlie the same IO-table. Hence, it is impossible to allocate value added to gross flows and any "solution" is essentially arbitrary.

Fortunately in empirical terms, the double counts have (so far) been minor. Table 4 provides information on the double count in VAX-D. It is defined as the sum of the bilateral VAX-D to all export partners minus the aggregate VAX-D, expressed as a percentage of the latter. It follows that this term is not large, and typically less than 1 per cent. The maximum (1.8 per 
cent) is found for the case of Germany, signifying that this country has sizeable back-and-forth trade that is bigger than for other countries. The lowest double counts are found for Australia and Brazil, countries that specialize in exporting natural resources. The value added generated in mining for exports is generally not returning to these countries in the form of intermediate inputs.

Table 4 VAX-D double counts, selected countries, 2014

\begin{tabular}{lc}
\hline & $\begin{array}{c}\text { VAX-D double } \\
\text { count }\end{array}$ \\
\hline Germany & $1.8 \%$ \\
China & $0.8 \%$ \\
United States & $0.7 \%$ \\
Japan & $0.3 \%$ \\
United Kingdom & $0.3 \%$ \\
Australia & $0.1 \%$ \\
Brazil & $0.1 \%$ \\
\hline
\end{tabular}

Note: VAX-D double count is the sum of the bilateral VAX-D to all partners minus the aggregate $V A X-D$. It is expressed as a percentage of aggregate VAX-D. Authors' calculations based on WIOD 2016 release.

\section{Concluding remarks}

In this paper we provided an integrated discussion of three useful measures of value added exports at the bilateral level: VAX-D as introduced by Los et al. (2016), VAX-C as introduced by Johnson and Noguera (2012) and VAX-P, a novel measure that indicates the value added used abroad in the final stage of production. We showed that the measures have different interpretations, while they belong to the same class of indicators. All can be derived with the method of hypothetical extraction in a general input-output model. In addition we show that the sum of bilateral measures for VAX-D might differ from the corresponding aggregate measure (as opposed to VAX-P and VAX-C). This happens if the country of interest is involved in feedback loops within production networks, i.e. if the production of exports of a country requires imported intermediates to which the country contributed value added in upstream stages of production. This is an inherent feature of intricate production networks. We illustrate all measures with some numerical examples using the World Input-Output Database and show that they do not only differ conceptually, but also empirically. 
Many extensions are possible, in particular using economic indicators other than value added, such as labor income or hours worked (see e.g. Chen et al., 2018). Progress will depend on the further availability of new and improved data sources. The popularity of VAX measures in the policy arena is not (yet) properly matched by the quality of the available data, as many gaps and inconsistencies in primary data collection remain. Harmonizing national and international data collection efforts and institutionalizing their production in regular statistical programs is a major challenge, see e.g. Landefeld (2015). Ongoing efforts in the international statistical community towards this goal are therefore very welcome and deserve full support.

\section{References}

Aichele, Rahel, Gabriel Felbermayr and Inga Heiland (2014). "Going Deep: The Trade and Welfare Effects of TTIP.” CESifo Working Paper 5150, CESifo Munich.

Bems, Rudolfs, Robert C. Johnson and Kei-Mu Yi (2011). "Vertical Linkages and the Collapse of Global Trade.” American Economic Review (Papers and Proceedings), 101(3), 30812.

Bems, Rudolfs, Robert C. Johnson and Kei-Mu Yi (2013). “The Great Trade Collapse.” Annual Review of Economics, 5(1), 375-400.

Blanchard, Emily, Chad P. Bown and Robert C. Johnson (2017). Global Value Chains and Trade Policy, mimeo, August 2017.

Brakman, Steven, Harry Garretsen and Tristan Kohl (2018). "Consequences of Brexit and Options for a 'Global Britain'.” Papers in Regional Science, 97(1), 55-72.

Chen, Wen, Bart Los, Philip McCann, Raquel Ortega-Argilés, Mark Thissen and Frank van Oort (2018). "The Continental Divide? Economic Exposure to Brexit in Regions and Countries on Both Sides of the Channel.” Papers in Regional Science, 97(1), 25-54.

Chenery, Hollis B. and Tsunehiko Watanabe (1958). "International Comparisons of the Structure of Production.” Econometrica, 26(4), 487-521.

Dhingra, Swati, Rebecca Freeman and Eleonora Mavroeidi (2018). "Beyond Tariff Reductions: What Extra Boost from Trade Agreement Provisions?” CEP Discussion Paper 1532, London School of Economics.

Dietzenbacher, Erik, Jan A. van der Linden and Albert E. Steenge (1993). "The Regional Extraction Method: EC Input-Output Comparisons." Economic Systems Research, 5(2), 185-206.

Hummels, D, J. Ishii and K.-M. Yi, (2001). “The Nature and Growth of Vertical Specialization in World Trade.” Journal of International Economics, 54 (1), 75-96.

Johnson, Robert C. (2014). "Five Facts about Value-Added Exports and Implications for Macroeconomics and Trade Research.” Journal of Economic Perspectives, 28(2), 11942.

Johnson, Robert C. (2017). “Measuring Global Value Chains.” NBER working paper \#24027. forthcoming in Annual Review of Economics. 
Johnson, Robert C. and Guillermo Noguera (2012). “Accounting for Intermediates: Production Sharing and Trade in Value Added.” Journal of International Economics, 86(2), 22436.

Johnson, Robert C. and Guillermo Noguera (2017). “A Portrait of Trade in Value Added over Four Decades.” Review of Economics and Statistics, 99(5), 896-911.

Kaplan, Lennart C., Tristan Kohl and Inmaculada Martinez-Zarzoso (2018). "Supply-Chain Trade and Labor Market Outcomes: The Case of the 2004 European Union Enlargement.” Review of International Economics, 26(2), 481-506.

Koopman, Robert, Zhi Wang and Shang-Jin Wei (2012). "Estimating Domestic Content in Exports when Processing Trade is Pervasive." Journal of Development Economics, 99(1), 178-89.

Koopman, Robert, Zhi Wang and Shang-Jin Wei (2014). “Tracing Value-Added and Double Counting in Gross Exports.” American Economic Review, 104(2), 459-94.

Laget, Edith, Alberto Osnago, Nadia Rocha and Michele Ruta (2018). "Deep Trade Agreements and Global Value Chains.” Policy Research Working Paper 8491, World Bank.

Landefeld, J. Steven (2015), Handbook for a System of Extended International and Global Accounts (SEIGA) Overview of Major Issues, draft November 23 for United Nations Statistical Division.

Los, Bart, Marcel P. Timmer and Gaaitzen J. de Vries (2015). "How Global are Global Value Chains? A New Approach to Measure International Fragmentation.” Journal of Regional Science, 55(1), 66-92.

Los, Bart, Marcel P. Timmer and Gaaitzen J. de Vries (2016). “Tracing Value-Added and Double Counting in Gross Exports: Comment.” American Economic Review, 106(7), 1958-66.

Miller, Ronald E. (1966). "Interregional Feedback Effects in Input-Output Models: Some Preliminary Results." Papers in Regional Science, 17(1), 105-25.

Miller, Ronald E., and Michael L. Lahr (2001). “A Taxonomy of Extractions.” in: Michael L. Lahr and Ronald E. Miller (eds.), Regional Science Perspectives in Economic Analysis, Amsterdam: Elsevier Science, 407-41.

Morimoto, Yoshinori (1970). “On Aggregation Problems in Input-Output Analysis.” Review of Economic Studies, 37(1), 119-26.

Nagengast, Arne J. and Robert Stehrer (2016). "Accounting for the Differences Between Gross and Value Added Trade Balances." The World Economy, 39(9), 1276-1306.

Noguera, Guillermo (2012). "Trade Costs and Gravity for Gross and Value Added Trade." University of California at Berkeley and Columbia University, mimeo.

Nomaler, Z. Onder and Bart Verspagen (2014). Analysing Global Value Chains Using InputOutput Economics: Proceed with Care. (UNU-MERIT Working Papers Series, No. 2014070). Maastricht: UNU-MERIT

Paelinck, Jean, Jean de Caevel, and Joseph Degueldre (1965). “Analyse Quantitative de Certaines Phénomènes du Développement Régional Polarisé: Essai de Simulation Statique d'Itéraires de Propagation.” In Problèmes de Conversion Économique: Analyses Théoriques et Études Appliquées, Bibliothèque de l’Institut de Science Économique, No. 7, 341-87. Paris: M.-Th. Génin. 
Simpson, David and Jinkichi Tsukui (1965). "The Fundamental Structure of Input-Output Tables, An International Comparison.” Review of Economics and Statistics, 47(4), 43446

Strassert, Günter (1968), "Zur Bestimmung strategischer Sektoren mit Hilfe von Input-OutputModellen.” Jahrbücher für Nationalökonomie und Statistik, 182(3), 211-15.

Timmer, Marcel P., Erik Dietzenbacher, Bart Los, Robert Stehrer and Gaaitzen J. de Vries (2015). "An Illustrated User Guide to the World Input-Output Database: the Case of Global Automotive Production.” Review of International Economics, 23(3), 575-605.

Wang, Zhi, Shang-Jin Wei and Kunfu Zhu (2018). "Quantifying International Production Sharing At The Bilateral And Sector Levels.” NBER Working paper w19677 revised version. 
Appendix Table A1 Bilateral exports by China, 2014.

\begin{tabular}{|c|c|c|c|c|c|c|c|c|c|c|c|c|}
\hline & \multicolumn{4}{|c|}{ million US\$ } & \multicolumn{4}{|c|}{ Shares in total } & \multicolumn{4}{|c|}{ Ranking of countries } \\
\hline & GX & VAX-D & VAX-P & VAX-C & GX & VAX-D & VAX-P & VAX-C & GX & VAX-D & VAX-P & VAX-C \\
\hline United States & 347,311 & 280,320 & 123,637 & 320,289 & $14.3 \%$ & $14.0 \%$ & $13.1 \%$ & $16.7 \%$ & 1 & 1 & 1 & 1 \\
\hline Japan & 172,861 & 140,285 & 55,341 & 137,386 & $7.1 \%$ & $7.0 \%$ & $5.9 \%$ & $7.1 \%$ & 2 & 2 & 2 & 2 \\
\hline South Korea & 101,924 & 81,605 & 46,955 & 56,392 & $4.2 \%$ & $4.1 \%$ & $5.0 \%$ & $2.9 \%$ & 3 & 3 & 3 & 5 \\
\hline Germany & 88,465 & 72,334 & 35,614 & 71,375 & $3.6 \%$ & $3.6 \%$ & $3.8 \%$ & $3.7 \%$ & 4 & 4 & 4 & 3 \\
\hline Russian Federation & 65,198 & 56,474 & 14,834 & 62,062 & $2.7 \%$ & $2.8 \%$ & $1.6 \%$ & $3.2 \%$ & 5 & 5 & 13 & 4 \\
\hline United Kingdom & 51,850 & 42,270 & 21,216 & 49,968 & $2.1 \%$ & $2.1 \%$ & $2.3 \%$ & $2.6 \%$ & 6 & 6 & 8 & 6 \\
\hline Canada & 49,636 & 40,763 & 21,667 & 43,000 & $2.0 \%$ & $2.0 \%$ & $2.3 \%$ & $2.2 \%$ & 7 & 7 & 7 & 8 \\
\hline Australia & 48,459 & 39,568 & 19,714 & 43,198 & $2.0 \%$ & $2.0 \%$ & $2.1 \%$ & $2.2 \%$ & 8 & 8 & 10 & 7 \\
\hline India & 44,869 & 36,269 & 24,407 & 39,846 & $1.8 \%$ & $1.8 \%$ & $2.6 \%$ & $2.1 \%$ & 9 & 9 & 5 & 9 \\
\hline Taiwan & 43,622 & 34,210 & 14,413 & 20,401 & $1.8 \%$ & $1.7 \%$ & $1.5 \%$ & $1.1 \%$ & 10 & 11 & 14 & 16 \\
\hline Netherlands & 42,640 & 34,215 & 13,863 & 26,891 & $1.8 \%$ & $1.7 \%$ & $1.5 \%$ & $1.4 \%$ & 11 & 10 & 15 & 13 \\
\hline France & 41,291 & 34,061 & 21,759 & 38,267 & $1.7 \%$ & $1.7 \%$ & $2.3 \%$ & $2.0 \%$ & 12 & 12 & 6 & 10 \\
\hline Brazil & 38,988 & 31,703 & 19,966 & 36,926 & $1.6 \%$ & $1.6 \%$ & $2.1 \%$ & $1.9 \%$ & 13 & 13 & 9 & 11 \\
\hline Mexico & 38,330 & 30,554 & 17,932 & 25,082 & $1.6 \%$ & $1.5 \%$ & $1.9 \%$ & $1.3 \%$ & 14 & 14 & 12 & 15 \\
\hline Indonesia & 34,969 & 28,644 & 19,225 & 29,300 & $1.4 \%$ & $1.4 \%$ & $2.0 \%$ & $1.5 \%$ & 15 & 15 & 11 & 12 \\
\hline Italy & 28,865 & 23,873 & 13,690 & 25,699 & $1.2 \%$ & $1.2 \%$ & $1.5 \%$ & $1.3 \%$ & 16 & 16 & 16 & 14 \\
\hline Turkey & 23,149 & 18,558 & 10,112 & 18,765 & $1.0 \%$ & $0.9 \%$ & $1.1 \%$ & $1.0 \%$ & 17 & 17 & 17 & 18 \\
\hline Spain & 21,496 & 17,849 & 9,595 & 19,998 & $0.9 \%$ & $0.9 \%$ & $1.0 \%$ & $1.0 \%$ & 18 & 18 & 18 & 17 \\
\hline Poland & 14,316 & 11,541 & 5,868 & 11,771 & $0.6 \%$ & $0.6 \%$ & $0.6 \%$ & $0.6 \%$ & 19 & 19 & 20 & 19 \\
\hline Belgium & 11,804 & 9,862 & 6,303 & 9,490 & $0.5 \%$ & $0.5 \%$ & $0.7 \%$ & $0.5 \%$ & 20 & 20 & 19 & 20 \\
\hline Sweden & 11,173 & 9,445 & 5,849 & 9,005 & $0.5 \%$ & $0.5 \%$ & $0.6 \%$ & $0.5 \%$ & 21 & 21 & 21 & 21 \\
\hline Czech Republic & 8,898 & 6,855 & 3,952 & 4,800 & $0.4 \%$ & $0.3 \%$ & $0.4 \%$ & $0.2 \%$ & 22 & 22 & 22 & 27 \\
\hline Switzerland & 7,293 & 5,911 & 3,944 & 7,879 & $0.3 \%$ & $0.3 \%$ & $0.4 \%$ & $0.4 \%$ & 23 & 23 & 23 & 22 \\
\hline Finland & 6,870 & 5,644 & 3,781 & 5,056 & $0.3 \%$ & $0.3 \%$ & $0.4 \%$ & $0.3 \%$ & 24 & 24 & 24 & 25 \\
\hline Denmark & 6,199 & 5,215 & 3,553 & 5,101 & $0.3 \%$ & $0.3 \%$ & $0.4 \%$ & $0.3 \%$ & 25 & 25 & 25 & 24 \\
\hline Hungary & 5,396 & 4,135 & 3,035 & 2,342 & $0.2 \%$ & $0.2 \%$ & $0.3 \%$ & $0.1 \%$ & 26 & 26 & 26 & 32 \\
\hline Norway & 4,563 & 3,786 & 2,270 & 5,183 & $0.2 \%$ & $0.2 \%$ & $0.2 \%$ & $0.3 \%$ & 27 & 27 & 29 & 23 \\
\hline Austria & 4,242 & 3,500 & 2,493 & 4,875 & $0.2 \%$ & $0.2 \%$ & $0.3 \%$ & $0.3 \%$ & 28 & 28 & 27 & 26 \\
\hline Greece & 4,190 & 3,436 & 1,246 & 4,399 & $0.2 \%$ & $0.2 \%$ & $0.1 \%$ & $0.2 \%$ & 29 & 29 & 32 & 28 \\
\hline Ireland & 3,471 & 2,816 & 2,342 & 3,204 & $0.1 \%$ & $0.1 \%$ & $0.2 \%$ & $0.2 \%$ & 30 & 30 & 28 & 29 \\
\hline Romania & 2,614 & 2,089 & 1,573 & 2,850 & $0.1 \%$ & $0.1 \%$ & $0.2 \%$ & $0.1 \%$ & 31 & 31 & 31 & 30 \\
\hline Portugal & 2,251 & 1,844 & 1,219 & 2,620 & $0.1 \%$ & $0.1 \%$ & $0.1 \%$ & $0.1 \%$ & 32 & 32 & 33 & 31 \\
\hline Slovak Republic & 2,002 & 1,596 & 1,711 & 1,700 & $0.1 \%$ & $0.1 \%$ & $0.2 \%$ & $0.1 \%$ & 33 & 33 & 30 & 33 \\
\hline Slovenia & 1,369 & 1,137 & 482 & 1,167 & $0.1 \%$ & $0.1 \%$ & $0.1 \%$ & $0.1 \%$ & 34 & 34 & 35 & 34 \\
\hline Estonia & 1,073 & 862 & 457 & 683 & $0.0 \%$ & $0.0 \%$ & $0.0 \%$ & $0.0 \%$ & 35 & 35 & 37 & 39 \\
\hline Bulgaria & 1,029 & 847 & 536 & 1,150 & $0.0 \%$ & $0.0 \%$ & $0.1 \%$ & $0.1 \%$ & 36 & 36 & 34 & 35 \\
\hline Lithuania & 947 & 780 & 381 & 948 & $0.0 \%$ & $0.0 \%$ & $0.0 \%$ & $0.0 \%$ & 37 & 37 & 38 & 36 \\
\hline Luxembourg & 911 & 711 & 458 & 920 & $0.0 \%$ & $0.0 \%$ & $0.0 \%$ & $0.0 \%$ & 38 & 38 & 36 & 37 \\
\hline Croatia & 714 & 586 & 344 & 832 & $0.0 \%$ & $0.0 \%$ & $0.0 \%$ & $0.0 \%$ & 39 & 39 & 39 & 38 \\
\hline Latvia & 654 & 544 & 269 & 646 & $0.0 \%$ & $0.0 \%$ & $0.0 \%$ & $0.0 \%$ & 40 & 40 & 40 & 40 \\
\hline Cyprus & 583 & 487 & 189 & 569 & $0.0 \%$ & $0.0 \%$ & $0.0 \%$ & $0.0 \%$ & 41 & 41 & 42 & 41 \\
\hline Malta & 455 & 376 & 211 & 350 & $0.0 \%$ & $0.0 \%$ & $0.0 \%$ & $0.0 \%$ & 42 & 42 & 41 & 42 \\
\hline Rest of world & $1,038,525$ & 870,577 & 385,318 & 771,233 & $42.8 \%$ & $43.6 \%$ & $40.9 \%$ & $40.1 \%$ & & & & \\
\hline Sum of bilaterals & $2,425,464$ & $1,998,134$ & 941,724 & $1,923,618$ & $57 \%$ & $56 \%$ & $59 \%$ & $60 \%$ & & & & \\
\hline Aggregate & $2,425,464$ & $1,981,364$ & 941,724 & $1,923,618$ & & & & & & & & \\
\hline
\end{tabular}

Note: Authors' calculations based on WIOD, 2016 release. 
Appendix Table A2 Bilateral exports by United States of America, 2014.

\begin{tabular}{|c|c|c|c|c|c|c|c|c|c|c|c|c|}
\hline & \multicolumn{4}{|c|}{ million US\$ } & \multicolumn{4}{|c|}{ Shares in total } & \multicolumn{4}{|c|}{ Ranking of countries } \\
\hline & $\mathrm{GX}$ & VAX-D & VAX-P & VAX-C & GX & VAX-D & VAX-P & VAX-C & GX & VAX-D & VAX-P & VAX-C \\
\hline Canada & 291,930 & 242,458 & 120,217 & 185,228 & $15.1 \%$ & $14.5 \%$ & $11.7 \%$ & $12.0 \%$ & 1 & 1 & 1 & 1 \\
\hline Mexico & 178,587 & 146,127 & 91,872 & 99,465 & $9.3 \%$ & $8.7 \%$ & $9.0 \%$ & $6.4 \%$ & 2 & 2 & 2 & 3 \\
\hline China & 112,051 & 95,421 & 83,364 & 120,552 & $5.8 \%$ & $5.7 \%$ & $8.1 \%$ & $7.8 \%$ & 3 & 3 & 3 & 2 \\
\hline Germany & 79,939 & 70,486 & 46,817 & 69,805 & $4.1 \%$ & $4.2 \%$ & $4.6 \%$ & $4.5 \%$ & 4 & 4 & 4 & 5 \\
\hline United Kingdom & 73,796 & 62,847 & 35,678 & 69,873 & $3.8 \%$ & $3.7 \%$ & $3.5 \%$ & $4.5 \%$ & 5 & 5 & 7 & 4 \\
\hline Japan & 63,598 & 54,682 & 40,820 & 61,562 & $3.3 \%$ & $3.3 \%$ & $4.0 \%$ & $4.0 \%$ & 6 & 7 & 5 & 6 \\
\hline Ireland & 61,756 & 58,371 & 29,031 & 16,962 & $3.2 \%$ & $3.5 \%$ & $2.8 \%$ & $1.1 \%$ & 7 & 6 & 8 & 15 \\
\hline France & 57,720 & 49,924 & 37,565 & 49,212 & $3.0 \%$ & $3.0 \%$ & $3.7 \%$ & $3.2 \%$ & 8 & 8 & 6 & 7 \\
\hline Netherlands & 47,920 & 42,699 & 20,478 & 26,914 & $2.5 \%$ & $2.5 \%$ & $2.0 \%$ & $1.7 \%$ & 9 & 9 & 11 & 11 \\
\hline South Korea & 43,887 & 38,138 & 24,817 & 32,619 & $2.3 \%$ & $2.3 \%$ & $2.4 \%$ & $2.1 \%$ & 10 & 10 & 10 & 9 \\
\hline Brazil & 40,464 & 33,572 & 25,773 & 36,374 & $2.1 \%$ & $2.0 \%$ & $2.5 \%$ & $2.4 \%$ & 11 & 11 & 9 & 8 \\
\hline Belgium & 29,823 & 26,553 & 15,603 & 19,119 & $1.5 \%$ & $1.6 \%$ & $1.5 \%$ & $1.2 \%$ & 12 & 12 & 13 & 13 \\
\hline Australia & 26,813 & 23,109 & 13,636 & 27,004 & $1.4 \%$ & $1.4 \%$ & $1.3 \%$ & $1.7 \%$ & 13 & 13 & 15 & 10 \\
\hline Luxembourg & 20,862 & 19,896 & 7,786 & 2,130 & $1.1 \%$ & $1.2 \%$ & $0.8 \%$ & $0.1 \%$ & 14 & 14 & 18 & 32 \\
\hline Italy & 19,655 & 17,071 & 16,581 & 22,286 & $1.0 \%$ & $1.0 \%$ & $1.6 \%$ & $1.4 \%$ & 15 & 15 & 12 & 12 \\
\hline Taiwan & 16,415 & 13,934 & 7,661 & 10,924 & $0.9 \%$ & $0.8 \%$ & $0.7 \%$ & $0.7 \%$ & 16 & 17 & 20 & 20 \\
\hline India & 16,233 & 13,937 & 14,511 & 18,889 & $0.8 \%$ & $0.8 \%$ & $1.4 \%$ & $1.2 \%$ & 17 & 16 & 14 & 14 \\
\hline Sweden & 13,598 & 12,437 & 7,675 & 12,559 & $0.7 \%$ & $0.7 \%$ & $0.7 \%$ & $0.8 \%$ & 18 & 18 & 19 & 17 \\
\hline Switzerland & 13,415 & 11,797 & 9,671 & 12,484 & $0.7 \%$ & $0.7 \%$ & $0.9 \%$ & $0.8 \%$ & 19 & 19 & 16 & 19 \\
\hline Spain & 10,955 & 9,312 & 9,049 & 13,821 & $0.6 \%$ & $0.6 \%$ & $0.9 \%$ & $0.9 \%$ & 20 & 20 & 17 & 16 \\
\hline Turkey & 8,302 & 6,855 & 6,944 & 9,032 & $0.4 \%$ & $0.4 \%$ & $0.7 \%$ & $0.6 \%$ & 21 & 21 & 21 & 21 \\
\hline Russian Federation & 7,081 & 5,811 & 4,984 & 12,557 & $0.4 \%$ & $0.3 \%$ & $0.5 \%$ & $0.8 \%$ & 22 & 23 & 24 & 18 \\
\hline Denmark & 6,837 & 6,209 & 5,103 & 5,223 & $0.4 \%$ & $0.4 \%$ & $0.5 \%$ & $0.3 \%$ & 23 & 22 & 23 & 27 \\
\hline Norway & 6,564 & 5,726 & 4,271 & 6,797 & $0.3 \%$ & $0.3 \%$ & $0.4 \%$ & $0.4 \%$ & 24 & 24 & 25 & 23 \\
\hline Finland & 6,197 & 5,612 & 3,917 & 5,314 & $0.3 \%$ & $0.3 \%$ & $0.4 \%$ & $0.3 \%$ & 25 & 25 & 27 & 26 \\
\hline Indonesia & 5,864 & 5,069 & 6,458 & 8,331 & $0.3 \%$ & $0.3 \%$ & $0.6 \%$ & $0.5 \%$ & 26 & 26 & 22 & 22 \\
\hline Poland & 4,602 & 3,999 & 4,189 & 6,351 & $0.2 \%$ & $0.2 \%$ & $0.4 \%$ & $0.4 \%$ & 27 & 28 & 26 & 24 \\
\hline Austria & 4,581 & 4,031 & 3,834 & 5,504 & $0.2 \%$ & $0.2 \%$ & $0.4 \%$ & $0.4 \%$ & 28 & 27 & 28 & 25 \\
\hline Hungary & 3,402 & 3,093 & 2,582 & 2,523 & $0.2 \%$ & $0.2 \%$ & $0.3 \%$ & $0.2 \%$ & 29 & 29 & 29 & 30 \\
\hline Czech Republic & 2,746 & 2,439 & 2,570 & 2,985 & $0.1 \%$ & $0.1 \%$ & $0.3 \%$ & $0.2 \%$ & 30 & 30 & 30 & 29 \\
\hline Greece & 2,274 & 2,062 & 1,931 & 3,084 & $0.1 \%$ & $0.1 \%$ & $0.2 \%$ & $0.2 \%$ & 31 & 31 & 31 & 28 \\
\hline Portugal & 1,566 & 1,383 & 1,595 & 2,429 & $0.1 \%$ & $0.1 \%$ & $0.2 \%$ & $0.2 \%$ & 32 & 32 & 32 & 31 \\
\hline Romania & 1,223 & 1,042 & 1,376 & 2,000 & $0.1 \%$ & $0.1 \%$ & $0.1 \%$ & $0.1 \%$ & 33 & 33 & 33 & 33 \\
\hline Slovak Republic & 763 & 687 & 1,111 & 1,159 & $0.0 \%$ & $0.0 \%$ & $0.1 \%$ & $0.1 \%$ & 34 & 34 & 34 & 34 \\
\hline Bulgaria & 546 & 484 & 526 & 829 & $0.0 \%$ & $0.0 \%$ & $0.1 \%$ & $0.1 \%$ & 35 & 35 & 35 & 35 \\
\hline Croatia & 480 & 437 & 436 & 625 & $0.0 \%$ & $0.0 \%$ & $0.0 \%$ & $0.0 \%$ & 36 & 36 & 37 & 37 \\
\hline Lithuania & 435 & 368 & 269 & 659 & $0.0 \%$ & $0.0 \%$ & $0.0 \%$ & $0.0 \%$ & 37 & 37 & 39 & 36 \\
\hline Slovenia & 372 & 327 & 327 & 596 & $0.0 \%$ & $0.0 \%$ & $0.0 \%$ & $0.0 \%$ & 38 & 38 & 38 & 38 \\
\hline Malta & 356 & 313 & 491 & 285 & $0.0 \%$ & $0.0 \%$ & $0.0 \%$ & $0.0 \%$ & 39 & 39 & 36 & 42 \\
\hline Estonia & 252 & 221 & 227 & 360 & $0.0 \%$ & $0.0 \%$ & $0.0 \%$ & $0.0 \%$ & 40 & 40 & 40 & 40 \\
\hline Latvia & 233 & 207 & 213 & 394 & $0.0 \%$ & $0.0 \%$ & $0.0 \%$ & $0.0 \%$ & 41 & 41 & 41 & 39 \\
\hline Cyprus & 146 & 130 & 181 & 341 & $0.0 \%$ & $0.0 \%$ & $0.0 \%$ & $0.0 \%$ & 42 & 42 & 42 & 41 \\
\hline Rest of world & 642,853 & 577,983 & 312,213 & 559,590 & $33.4 \%$ & $34.5 \%$ & $30.5 \%$ & $36.2 \%$ & & & & \\
\hline Sum of bilaterals & $1,927,091$ & $1,677,256$ & $1,024,353$ & $1,544,752$ & $67 \%$ & $66 \%$ & $70 \%$ & $64 \%$ & & & & \\
\hline Aggregate & $1,927,091$ & $1,666,117$ & $1,024,353$ & $1,544,752$ & & & & & & & & \\
\hline
\end{tabular}

Note: Authors' calculations based on WIOD, 2016 release. 
Appendix Table A3 Bilateral exports by Germany, 2014.

\begin{tabular}{|c|c|c|c|c|c|c|c|c|c|c|c|c|}
\hline & \multicolumn{4}{|c|}{ million US\$ } & \multicolumn{4}{|c|}{ Shares in total } & \multicolumn{4}{|c|}{ Ranking of countries } \\
\hline & GX & VAX-D & VAX-P & VAX-C & $\mathrm{GX}$ & VAX-D & VAX-P & VAX-C & $\mathrm{GX}$ & VAX-D & VAX-P & VAX-C \\
\hline United States & 135,642 & 95,970 & 58,466 & 117,597 & $8.1 \%$ & $8.1 \%$ & $9.2 \%$ & $10.4 \%$ & 1 & 1 & 1 & 1 \\
\hline France & 133,788 & 92,097 & 49,683 & 82,206 & $8.0 \%$ & $7.8 \%$ & $7.8 \%$ & $7.3 \%$ & 2 & 2 & 3 & 3 \\
\hline China & 122,900 & 87,554 & 50,447 & 97,226 & $7.3 \%$ & $7.4 \%$ & $7.9 \%$ & $8.6 \%$ & 3 & 3 & 2 & 2 \\
\hline United Kingdom & 103,347 & 73,161 & 39,573 & 74,075 & $6.1 \%$ & $6.2 \%$ & $6.2 \%$ & $6.6 \%$ & 4 & 4 & 4 & 4 \\
\hline Italy & 84,740 & 58,590 & 33,124 & 49,916 & $5.0 \%$ & $5.0 \%$ & $5.2 \%$ & $4.4 \%$ & 5 & 5 & 5 & 5 \\
\hline Austria & 77,551 & 52,540 & 21,284 & 35,208 & $4.6 \%$ & $4.4 \%$ & $3.4 \%$ & $3.1 \%$ & 6 & 6 & 6 & 8 \\
\hline Netherlands & 72,853 & 48,837 & 19,555 & 32,708 & $4.3 \%$ & $4.1 \%$ & $3.1 \%$ & $2.9 \%$ & 7 & 7 & 9 & 9 \\
\hline Switzerland & 63,955 & 45,823 & 20,935 & 35,731 & $3.8 \%$ & $3.9 \%$ & $3.3 \%$ & $3.2 \%$ & 8 & 8 & 7 & 7 \\
\hline Poland & 61,604 & 41,328 & 20,485 & 31,549 & $3.7 \%$ & $3.5 \%$ & $3.2 \%$ & $2.8 \%$ & 9 & 9 & 8 & 11 \\
\hline Spain & 50,542 & 35,337 & 19,104 & 32,109 & $3.0 \%$ & $3.0 \%$ & $3.0 \%$ & $2.9 \%$ & 10 & 10 & 10 & 10 \\
\hline Russian Federation & 49,265 & 33,299 & 17,645 & 36,857 & $2.9 \%$ & $2.8 \%$ & $2.8 \%$ & $3.3 \%$ & 11 & 11 & 11 & 6 \\
\hline Czech Republic & 42,855 & 29,056 & 14,061 & 15,467 & $2.5 \%$ & $2.5 \%$ & $2.2 \%$ & $1.4 \%$ & 12 & 12 & 12 & 17 \\
\hline Belgium & 41,918 & 28,491 & 14,032 & 19,838 & $2.5 \%$ & $2.4 \%$ & $2.2 \%$ & $1.8 \%$ & 13 & 13 & 13 & 14 \\
\hline Sweden & 32,584 & 22,950 & 10,117 & 20,040 & $1.9 \%$ & $1.9 \%$ & $1.6 \%$ & $1.8 \%$ & 14 & 14 & 16 & 13 \\
\hline Turkey & 28,860 & 19,362 & 10,744 & 18,239 & $1.7 \%$ & $1.6 \%$ & $1.7 \%$ & $1.6 \%$ & 15 & 15 & 15 & 15 \\
\hline Hungary & 27,183 & 19,047 & 10,099 & 8,425 & $1.6 \%$ & $1.6 \%$ & $1.6 \%$ & $0.7 \%$ & 16 & 16 & 17 & 27 \\
\hline South Korea & 25,415 & 17,721 & 9,823 & 16,690 & $1.5 \%$ & $1.5 \%$ & $1.5 \%$ & $1.5 \%$ & 17 & 17 & 18 & 16 \\
\hline Japan & 24,757 & 17,315 & 12,309 & 22,324 & $1.5 \%$ & $1.5 \%$ & $1.9 \%$ & $2.0 \%$ & 18 & 18 & 14 & 12 \\
\hline Denmark & 24,165 & 16,554 & 9,784 & 11,677 & $1.4 \%$ & $1.4 \%$ & $1.5 \%$ & $1.0 \%$ & 19 & 19 & 19 & 21 \\
\hline Brazil & 17,775 & 12,327 & 9,248 & 15,288 & $1.1 \%$ & $1.0 \%$ & $1.5 \%$ & $1.4 \%$ & 20 & 20 & 20 & 18 \\
\hline Canada & 17,148 & 12,039 & 7,501 & 14,709 & $1.0 \%$ & $1.0 \%$ & $1.2 \%$ & $1.3 \%$ & 21 & 21 & 22 & 19 \\
\hline Finland & 15,078 & 10,670 & 5,867 & 8,688 & $0.9 \%$ & $0.9 \%$ & $0.9 \%$ & $0.8 \%$ & 22 & 22 & 25 & 25 \\
\hline Mexico & 14,849 & 10,388 & 7,519 & 10,197 & $0.9 \%$ & $0.9 \%$ & $1.2 \%$ & $0.9 \%$ & 23 & 23 & 21 & 23 \\
\hline Slovak Republic & 14,645 & 10,062 & 5,918 & 5,840 & $0.9 \%$ & $0.9 \%$ & $0.9 \%$ & $0.5 \%$ & 24 & 24 & 24 & 31 \\
\hline Romania & 13,071 & 9,083 & 5,177 & 8,676 & $0.8 \%$ & $0.8 \%$ & $0.8 \%$ & $0.8 \%$ & 25 & 25 & 26 & 26 \\
\hline India & 13,025 & 8,964 & 7,302 & 11,778 & $0.8 \%$ & $0.8 \%$ & $1.1 \%$ & $1.0 \%$ & 26 & 26 & 23 & 20 \\
\hline Norway & 12,835 & 8,880 & 4,694 & 9,832 & $0.8 \%$ & $0.8 \%$ & $0.7 \%$ & $0.9 \%$ & 27 & 27 & 28 & 24 \\
\hline Australia & 12,143 & 8,540 & 4,795 & 11,568 & $0.7 \%$ & $0.7 \%$ & $0.8 \%$ & $1.0 \%$ & 28 & 28 & 27 & 22 \\
\hline Taiwan & 10,385 & 7,129 & 3,086 & 6,073 & $0.6 \%$ & $0.6 \%$ & $0.5 \%$ & $0.5 \%$ & 29 & 30 & 31 & 30 \\
\hline Luxembourg & 10,284 & 7,548 & 2,671 & 3,816 & $0.6 \%$ & $0.6 \%$ & $0.4 \%$ & $0.3 \%$ & 30 & 29 & 33 & 34 \\
\hline Portugal & 9,998 & 6,895 & 3,358 & 6,489 & $0.6 \%$ & $0.6 \%$ & $0.5 \%$ & $0.6 \%$ & 31 & 32 & 30 & 28 \\
\hline Ireland & 9,475 & 7,077 & 4,238 & 5,174 & $0.6 \%$ & $0.6 \%$ & $0.7 \%$ & $0.5 \%$ & 32 & 31 & 29 & 32 \\
\hline Greece & 7,710 & 5,514 & 1,975 & 6,266 & $0.5 \%$ & $0.5 \%$ & $0.3 \%$ & $0.6 \%$ & 33 & 33 & 34 & 29 \\
\hline Slovenia & 4,664 & 3,232 & 1,416 & 2,506 & $0.3 \%$ & $0.3 \%$ & $0.2 \%$ & $0.2 \%$ & 34 & 34 & 35 & 36 \\
\hline Indonesia & 4,215 & 2,916 & 2,820 & 4,492 & $0.3 \%$ & $0.2 \%$ & $0.4 \%$ & $0.4 \%$ & 35 & 35 & 32 & 33 \\
\hline Bulgaria & 4,150 & 2,852 & 1,303 & 2,877 & $0.2 \%$ & $0.2 \%$ & $0.2 \%$ & $0.3 \%$ & 36 & 36 & 36 & 35 \\
\hline Croatia & 3,231 & 2,268 & 1,138 & 2,369 & $0.2 \%$ & $0.2 \%$ & $0.2 \%$ & $0.2 \%$ & 37 & 37 & 37 & 37 \\
\hline Lithuania & 2,752 & 1,882 & 705 & 1,888 & $0.2 \%$ & $0.2 \%$ & $0.1 \%$ & $0.2 \%$ & 38 & 38 & 38 & 38 \\
\hline Estonia & 2,139 & 1,427 & 652 & 1,166 & $0.1 \%$ & $0.1 \%$ & $0.1 \%$ & $0.1 \%$ & 39 & 39 & 39 & 39 \\
\hline Latvia & 1,396 & 964 & 459 & 1,085 & $0.1 \%$ & $0.1 \%$ & $0.1 \%$ & $0.1 \%$ & 40 & 40 & 40 & 40 \\
\hline Cyprus & 924 & 668 & 231 & 735 & $0.1 \%$ & $0.1 \%$ & $0.0 \%$ & $0.1 \%$ & 41 & 41 & 42 & 41 \\
\hline Malta & 442 & 320 & 246 & 307 & $0.0 \%$ & $0.0 \%$ & $0.0 \%$ & $0.0 \%$ & 42 & 42 & 41 & 42 \\
\hline Rest of world & 275,991 & 204,172 & 111,575 & 226,516 & $16.4 \%$ & $17.3 \%$ & $17.6 \%$ & $20.1 \%$ & & & & \\
\hline Sum of bilaterals & $1,682,253$ & $1,180,849$ & 635,165 & $1,126,218$ & $84 \%$ & $83 \%$ & $82 \%$ & $80 \%$ & & & & \\
\hline Aggregate & $1,682,253$ & $1,159,581$ & 635,165 & $1,126,218$ & & & & & & & & \\
\hline
\end{tabular}

Note: Authors' calculations based on WIOD, 2016 release. 
Appendix Table A4 Bilateral exports by Japan, 2014.

\begin{tabular}{|c|c|c|c|c|c|c|c|c|c|c|c|c|}
\hline & \multicolumn{4}{|c|}{ million US\$ } & \multicolumn{4}{|c|}{ Shares in total } & \multicolumn{4}{|c|}{ Ranking of countries } \\
\hline & GX & VAX-D & VAX-P & VAX-C & GX & VAX-D & VAX-P & VAX-C & GX & VAX-D & VAX-P & VAX-C \\
\hline China & 129,230 & 93,215 & 67,837 & 95,238 & $15.8 \%$ & $15.3 \%$ & $19.6 \%$ & $15.9 \%$ & 1 & 1 & 1 & 2 \\
\hline United States & 121,144 & 89,546 & 50,727 & 104,210 & $14.8 \%$ & $14.7 \%$ & $14.6 \%$ & $17.4 \%$ & 2 & 2 & 2 & 1 \\
\hline South Korea & 56,449 & 37,847 & 23,791 & 22,927 & $6.9 \%$ & $6.2 \%$ & $6.9 \%$ & $3.8 \%$ & 3 & 3 & 3 & 3 \\
\hline Taiwan & 44,809 & 31,139 & 12,680 & 16,457 & $5.5 \%$ & $5.1 \%$ & $3.7 \%$ & $2.7 \%$ & 4 & 4 & 4 & 4 \\
\hline Germany & 20,383 & 15,187 & 9,546 & 15,068 & $2.5 \%$ & $2.5 \%$ & $2.8 \%$ & $2.5 \%$ & 5 & 5 & 5 & 5 \\
\hline Indonesia & 16,155 & 11,296 & 9,496 & 11,389 & $2.0 \%$ & $1.9 \%$ & $2.7 \%$ & $1.9 \%$ & 6 & 6 & 6 & 8 \\
\hline Mexico & 14,993 & 11,081 & 8,487 & 9,028 & $1.8 \%$ & $1.8 \%$ & $2.4 \%$ & $1.5 \%$ & 7 & 7 & 7 & 11 \\
\hline Australia & 14,950 & 10,140 & 4,710 & 11,992 & $1.8 \%$ & $1.7 \%$ & $1.4 \%$ & $2.0 \%$ & 8 & 9 & 12 & 7 \\
\hline Russian Federation & 14,597 & 11,026 & 3,506 & 13,274 & $1.8 \%$ & $1.8 \%$ & $1.0 \%$ & $2.2 \%$ & 9 & 8 & 14 & 6 \\
\hline Canada & 11,500 & 8,678 & 6,272 & 10,190 & $1.4 \%$ & $1.4 \%$ & $1.8 \%$ & $1.7 \%$ & 10 & 10 & 8 & 9 \\
\hline United Kingdom & 9,647 & 7,403 & 5,970 & 10,143 & $1.2 \%$ & $1.2 \%$ & $1.7 \%$ & $1.7 \%$ & 11 & 11 & 9 & 10 \\
\hline India & 8,031 & 5,347 & 5,889 & 7,615 & $1.0 \%$ & $0.9 \%$ & $1.7 \%$ & $1.3 \%$ & 12 & 13 & 10 & 12 \\
\hline Netherlands & 7,893 & 5,888 & 3,107 & 5,041 & $1.0 \%$ & $1.0 \%$ & $0.9 \%$ & $0.8 \%$ & 13 & 12 & 15 & 15 \\
\hline France & 6,978 & 5,232 & 4,768 & 7,393 & $0.9 \%$ & $0.9 \%$ & $1.4 \%$ & $1.2 \%$ & 14 & 14 & 11 & 13 \\
\hline Brazil & 5,558 & 4,082 & 4,380 & 6,676 & $0.7 \%$ & $0.7 \%$ & $1.3 \%$ & $1.1 \%$ & 15 & 15 & 13 & 14 \\
\hline Belgium & 3,808 & 2,838 & 1,885 & 2,562 & $0.5 \%$ & $0.5 \%$ & $0.5 \%$ & $0.4 \%$ & 16 & 16 & 17 & 19 \\
\hline Italy & 3,135 & 2,369 & 2,709 & 3,981 & $0.4 \%$ & $0.4 \%$ & $0.8 \%$ & $0.7 \%$ & 17 & 17 & 16 & 16 \\
\hline Spain & 2,794 & 2,121 & 1,807 & 3,450 & $0.3 \%$ & $0.3 \%$ & $0.5 \%$ & $0.6 \%$ & 18 & 18 & 19 & 17 \\
\hline Turkey & 2,587 & 1,853 & 1,846 & 2,873 & $0.3 \%$ & $0.3 \%$ & $0.5 \%$ & $0.5 \%$ & 19 & 21 & 18 & 18 \\
\hline Switzerland & 2,495 & 1,958 & 1,290 & 2,335 & $0.3 \%$ & $0.3 \%$ & $0.4 \%$ & $0.4 \%$ & 20 & 20 & 21 & 20 \\
\hline Ireland & 2,485 & 2,040 & 1,302 & 1,374 & $0.3 \%$ & $0.3 \%$ & $0.4 \%$ & $0.2 \%$ & 21 & 19 & 20 & 24 \\
\hline Poland & 2,017 & 1,497 & 1,097 & 2,219 & $0.2 \%$ & $0.2 \%$ & $0.3 \%$ & $0.4 \%$ & 22 & 22 & 22 & 21 \\
\hline Sweden & 1,524 & 1,152 & 738 & 1,695 & $0.2 \%$ & $0.2 \%$ & $0.2 \%$ & $0.3 \%$ & 23 & 23 & 25 & 22 \\
\hline Norway & 1,476 & 1,071 & 598 & 1,412 & $0.2 \%$ & $0.2 \%$ & $0.2 \%$ & $0.2 \%$ & 24 & 24 & 27 & 23 \\
\hline Czech Republic & 1,396 & 1,041 & 873 & 911 & $0.2 \%$ & $0.2 \%$ & $0.3 \%$ & $0.2 \%$ & 25 & 25 & 23 & 26 \\
\hline Austria & 1,245 & 904 & 646 & 1,260 & $0.2 \%$ & $0.1 \%$ & $0.2 \%$ & $0.2 \%$ & 26 & 26 & 26 & 25 \\
\hline Hungary & 1,146 & 873 & 773 & 532 & $0.1 \%$ & $0.1 \%$ & $0.2 \%$ & $0.1 \%$ & 27 & 27 & 24 & 30 \\
\hline Finland & 546 & 409 & 432 & 647 & $0.1 \%$ & $0.1 \%$ & $0.1 \%$ & $0.1 \%$ & 28 & 28 & 30 & 28 \\
\hline Denmark & 512 & 403 & 552 & 694 & $0.1 \%$ & $0.1 \%$ & $0.2 \%$ & $0.1 \%$ & 29 & 29 & 28 & 27 \\
\hline Slovak Republic & 367 & 277 & 495 & 367 & $0.0 \%$ & $0.0 \%$ & $0.1 \%$ & $0.1 \%$ & 30 & 30 & 29 & 33 \\
\hline Portugal & 342 & 256 & 310 & 482 & $0.0 \%$ & $0.0 \%$ & $0.1 \%$ & $0.1 \%$ & 31 & 32 & 32 & 31 \\
\hline Luxembourg & 325 & 274 & 192 & 267 & $0.0 \%$ & $0.0 \%$ & $0.1 \%$ & $0.0 \%$ & 32 & 31 & 34 & 34 \\
\hline Greece & 241 & 183 & 200 & 585 & $0.0 \%$ & $0.0 \%$ & $0.1 \%$ & $0.1 \%$ & 33 & 33 & 33 & 29 \\
\hline Romania & 233 & 168 & 320 & 465 & $0.0 \%$ & $0.0 \%$ & $0.1 \%$ & $0.1 \%$ & 34 & 34 & 31 & 32 \\
\hline Cyprus & 150 & 115 & 21 & 158 & $0.0 \%$ & $0.0 \%$ & $0.0 \%$ & $0.0 \%$ & 35 & 35 & 42 & 37 \\
\hline Estonia & 128 & 95 & 58 & 134 & $0.0 \%$ & $0.0 \%$ & $0.0 \%$ & $0.0 \%$ & 36 & 36 & 37 & 38 \\
\hline Slovenia & 101 & 74 & 84 & 162 & $0.0 \%$ & $0.0 \%$ & $0.0 \%$ & $0.0 \%$ & 37 & 37 & 36 & 36 \\
\hline Bulgaria & 84 & 62 & 103 & 180 & $0.0 \%$ & $0.0 \%$ & $0.0 \%$ & $0.0 \%$ & 38 & 38 & 35 & 35 \\
\hline Malta & 41 & 29 & 36 & 48 & $0.0 \%$ & $0.0 \%$ & $0.0 \%$ & $0.0 \%$ & 39 & 39 & 41 & 42 \\
\hline Lithuania & 33 & 25 & 57 & 116 & $0.0 \%$ & $0.0 \%$ & $0.0 \%$ & $0.0 \%$ & 40 & 40 & 39 & 39 \\
\hline Croatia & 27 & 21 & 57 & 114 & $0.0 \%$ & $0.0 \%$ & $0.0 \%$ & $0.0 \%$ & 41 & 41 & 38 & 40 \\
\hline Latvia & 25 & 18 & 36 & 68 & $0.0 \%$ & $0.0 \%$ & $0.0 \%$ & $0.0 \%$ & 42 & 42 & 40 & 41 \\
\hline Rest of world & 305,935 & 241,127 & 107,149 & 224,819 & $37.4 \%$ & $39.5 \%$ & $30.9 \%$ & $37.4 \%$ & & & & \\
\hline Sum of bilaterals & 817,514 & 610,362 & 346,832 & 600,551 & $63 \%$ & $60 \%$ & $69 \%$ & $63 \%$ & & & & \\
\hline Aggregate & 817,514 & 608,320 & 346,832 & 600,551 & & & & & & & & \\
\hline
\end{tabular}

Note: Authors' calculations based on WIOD, 2016 release. 
Appendix Table A5 Bilateral exports by United Kingdom, 2014.

\begin{tabular}{|c|c|c|c|c|c|c|c|c|c|c|c|c|}
\hline & \multicolumn{4}{|c|}{ million US\$ } & \multicolumn{4}{|c|}{ Shares in total } & \multicolumn{4}{|c|}{ Ranking of countries } \\
\hline & GX & VAX-D & VAX-P & VAX-C & GX & VAX-D & VAX-P & VAX-C & GX & VAX-D & VAX-P & VAX-C \\
\hline United States & 85,559 & 64,519 & 47,428 & 77,249 & $11.4 \%$ & $11.1 \%$ & $12.9 \%$ & $13.6 \%$ & 1 & 1 & 1 & 1 \\
\hline Germany & 54,147 & 40,702 & 25,403 & 36,615 & $7.2 \%$ & $7.0 \%$ & $6.9 \%$ & $6.4 \%$ & 2 & 2 & 3 & 2 \\
\hline France & 46,573 & 36,845 & 25,954 & 34,209 & $6.2 \%$ & $6.3 \%$ & $7.1 \%$ & $6.0 \%$ & 3 & 3 & 2 & 3 \\
\hline Ireland & 34,477 & 27,275 & 13,478 & 14,828 & $4.6 \%$ & $4.7 \%$ & $3.7 \%$ & $2.6 \%$ & 4 & 4 & 5 & 6 \\
\hline China & 27,405 & 19,194 & 18,140 & 29,480 & $3.6 \%$ & $3.3 \%$ & $4.9 \%$ & $5.2 \%$ & 5 & 6 & 4 & 4 \\
\hline Luxembourg & 23,757 & 20,654 & 8,153 & 2,404 & $3.2 \%$ & $3.6 \%$ & $2.2 \%$ & $0.4 \%$ & 6 & 5 & 8 & 29 \\
\hline Netherlands & 23,602 & 17,874 & 8,065 & 12,956 & $3.1 \%$ & $3.1 \%$ & $2.2 \%$ & $2.3 \%$ & 7 & 7 & 10 & 8 \\
\hline Italy & 21,798 & 17,132 & 11,863 & 17,953 & $2.9 \%$ & $2.9 \%$ & $3.2 \%$ & $3.2 \%$ & 8 & 8 & 6 & 5 \\
\hline Belgium & 21,045 & 16,017 & 8,138 & 11,526 & $2.8 \%$ & $2.8 \%$ & $2.2 \%$ & $2.0 \%$ & 9 & 9 & 9 & 11 \\
\hline Switzerland & 19,449 & 15,218 & 7,844 & 13,332 & $2.6 \%$ & $2.6 \%$ & $2.1 \%$ & $2.3 \%$ & 10 & 10 & 12 & 7 \\
\hline Canada & 17,523 & 13,282 & 9,360 & 12,365 & $2.3 \%$ & $2.3 \%$ & $2.5 \%$ & $2.2 \%$ & 11 & 11 & 7 & 10 \\
\hline Russian Federation & 14,236 & 10,309 & 3,625 & 12,742 & $1.9 \%$ & $1.8 \%$ & $1.0 \%$ & $2.2 \%$ & 12 & 12 & 20 & 9 \\
\hline Spain & 12,959 & 9,666 & 5,975 & 10,234 & $1.7 \%$ & $1.7 \%$ & $1.6 \%$ & $1.8 \%$ & 13 & 13 & 13 & 13 \\
\hline Sweden & 11,769 & 9,048 & 4,627 & 7,796 & $1.6 \%$ & $1.6 \%$ & $1.3 \%$ & $1.4 \%$ & 14 & 14 & 17 & 15 \\
\hline Norway & 11,426 & 8,671 & 5,017 & 7,679 & $1.5 \%$ & $1.5 \%$ & $1.4 \%$ & $1.3 \%$ & 15 & 15 & 16 & 16 \\
\hline Japan & 9,919 & 7,414 & 8,036 & 11,280 & $1.3 \%$ & $1.3 \%$ & $2.2 \%$ & $2.0 \%$ & 16 & 16 & 11 & 12 \\
\hline South Korea & 9,694 & 7,405 & 5,808 & 7,148 & $1.3 \%$ & $1.3 \%$ & $1.6 \%$ & $1.3 \%$ & 17 & 17 & 14 & 17 \\
\hline Australia & 8,990 & 6,920 & 3,998 & 8,393 & $1.2 \%$ & $1.2 \%$ & $1.1 \%$ & $1.5 \%$ & 18 & 18 & 19 & 14 \\
\hline Denmark & 8,101 & 6,271 & 4,354 & 4,900 & $1.1 \%$ & $1.1 \%$ & $1.2 \%$ & $0.9 \%$ & 19 & 19 & 18 & 21 \\
\hline India & 7,260 & 4,781 & 5,528 & 6,261 & $1.0 \%$ & $0.8 \%$ & $1.5 \%$ & $1.1 \%$ & 20 & 21 & 15 & 18 \\
\hline Poland & 7,153 & 5,509 & 3,281 & 5,880 & $1.0 \%$ & $0.9 \%$ & $0.9 \%$ & $1.0 \%$ & 21 & 20 & 22 & 20 \\
\hline Turkey & 6,082 & 4,262 & 3,042 & 4,662 & $0.8 \%$ & $0.7 \%$ & $0.8 \%$ & $0.8 \%$ & 22 & 22 & 23 & 22 \\
\hline Brazil & 5,091 & 3,838 & 3,439 & 5,885 & $0.7 \%$ & $0.7 \%$ & $0.9 \%$ & $1.0 \%$ & 23 & 23 & 21 & 19 \\
\hline Finland & 3,784 & 2,940 & 1,957 & 2,810 & $0.5 \%$ & $0.5 \%$ & $0.5 \%$ & $0.5 \%$ & 24 & 24 & 26 & 25 \\
\hline Austria & 3,486 & 2,658 & 2,061 & 3,342 & $0.5 \%$ & $0.5 \%$ & $0.6 \%$ & $0.6 \%$ & 25 & 25 & 25 & 24 \\
\hline Czech Republic & 3,060 & 2,313 & 1,654 & 2,051 & $0.4 \%$ & $0.4 \%$ & $0.5 \%$ & $0.4 \%$ & 26 & 27 & 27 & 30 \\
\hline Portugal & 3,050 & 2,372 & 1,433 & 2,606 & $0.4 \%$ & $0.4 \%$ & $0.4 \%$ & $0.5 \%$ & 27 & 26 & 28 & 26 \\
\hline Mexico & 2,784 & 2,134 & 2,616 & 3,705 & $0.4 \%$ & $0.4 \%$ & $0.7 \%$ & $0.7 \%$ & 28 & 28 & 24 & 23 \\
\hline Greece & 2,627 & 2,097 & 1,131 & 2,588 & $0.3 \%$ & $0.4 \%$ & $0.3 \%$ & $0.5 \%$ & 29 & 29 & 33 & 27 \\
\hline Taiwan & 2,228 & 1,705 & 1,403 & 2,453 & $0.3 \%$ & $0.3 \%$ & $0.4 \%$ & $0.4 \%$ & 30 & 31 & 30 & 28 \\
\hline Hungary & 2,122 & 1,657 & 1,249 & 1,339 & $0.3 \%$ & $0.3 \%$ & $0.3 \%$ & $0.2 \%$ & 31 & 32 & 31 & 33 \\
\hline Malta & 1,983 & 1,717 & 1,175 & 653 & $0.3 \%$ & $0.3 \%$ & $0.3 \%$ & $0.1 \%$ & 32 & 30 & 32 & 37 \\
\hline Romania & 1,567 & 1,204 & 988 & 1,547 & $0.2 \%$ & $0.2 \%$ & $0.3 \%$ & $0.3 \%$ & 33 & 33 & 34 & 32 \\
\hline Cyprus & 1,080 & 853 & 303 & 836 & $0.1 \%$ & $0.1 \%$ & $0.1 \%$ & $0.1 \%$ & 34 & 34 & 37 & 34 \\
\hline Indonesia & 972 & 722 & 1,415 & 1,993 & $0.1 \%$ & $0.1 \%$ & $0.4 \%$ & $0.4 \%$ & 35 & 35 & 29 & 31 \\
\hline Slovak Republic & 810 & 605 & 608 & 730 & $0.1 \%$ & $0.1 \%$ & $0.2 \%$ & $0.1 \%$ & 36 & 36 & 35 & 35 \\
\hline Bulgaria & 754 & 577 & 349 & 676 & $0.1 \%$ & $0.1 \%$ & $0.1 \%$ & $0.1 \%$ & 37 & 37 & 36 & 36 \\
\hline Lithuania & 544 & 409 & 191 & 499 & $0.1 \%$ & $0.1 \%$ & $0.1 \%$ & $0.1 \%$ & 38 & 39 & 41 & 39 \\
\hline Croatia & 521 & 420 & 294 & 519 & $0.1 \%$ & $0.1 \%$ & $0.1 \%$ & $0.1 \%$ & 39 & 38 & 38 & 38 \\
\hline Estonia & 476 & 364 & 177 & 393 & $0.1 \%$ & $0.1 \%$ & $0.0 \%$ & $0.1 \%$ & 40 & 40 & 42 & 41 \\
\hline Latvia & 465 & 359 & 194 & 416 & $0.1 \%$ & $0.1 \%$ & $0.1 \%$ & $0.1 \%$ & 41 & 41 & 40 & 40 \\
\hline Slovenia & 421 & 315 & 225 & 376 & $0.1 \%$ & $0.1 \%$ & $0.1 \%$ & $0.1 \%$ & 42 & 42 & 39 & 42 \\
\hline Rest of world & 230,852 & 183,150 & 107,091 & 184,102 & $30.7 \%$ & $31.5 \%$ & $29.2 \%$ & $32.3 \%$ & & & & \\
\hline Sum of bilaterals & 751,599 & 581,373 & 367,067 & 569,411 & $69 \%$ & $68 \%$ & $71 \%$ & $68 \%$ & & & & \\
\hline Aggregate & 751,599 & 579,453 & 367,067 & 569,411 & & & & & & & & \\
\hline
\end{tabular}

Note: Authors' calculations based on WIOD, 2016 release. 
Appendix Table A6 Bilateral exports by Australia, 2014.

\begin{tabular}{|c|c|c|c|c|c|c|c|c|c|c|c|c|}
\hline & \multicolumn{4}{|c|}{ million US\$ } & \multicolumn{4}{|c|}{ Shares in total } & \multicolumn{4}{|c|}{ Ranking of countries } \\
\hline & GX & VAX-D & VAX-P & VAX-C & GX & VAX-D & VAX-P & VAX-C & $\mathrm{GX}$ & VAX-D & VAX-P & VAX-C \\
\hline China & 76,645 & 64,395 & 59,484 & 59,182 & $26.7 \%$ & $26.7 \%$ & $29.5 \%$ & $24.8 \%$ & 1 & 1 & 1 & 1 \\
\hline Japan & 46,272 & 39,248 & 30,752 & 32,570 & $16.1 \%$ & $16.3 \%$ & $15.3 \%$ & $13.6 \%$ & 2 & 2 & 2 & 2 \\
\hline South Korea & 16,058 & 13,436 & 9,498 & 8,734 & $5.6 \%$ & $5.6 \%$ & $4.7 \%$ & $3.7 \%$ & 3 & 3 & 4 & 4 \\
\hline Taiwan & 11,409 & 9,636 & 5,196 & 4,717 & $4.0 \%$ & $4.0 \%$ & $2.6 \%$ & $2.0 \%$ & 4 & 4 & 6 & 7 \\
\hline United States & 10,161 & 8,294 & 9,546 & 17,430 & $3.5 \%$ & $3.4 \%$ & $4.7 \%$ & $7.3 \%$ & 5 & 5 & 3 & 3 \\
\hline India & 7,844 & 6,305 & 6,625 & 6,661 & $2.7 \%$ & $2.6 \%$ & $3.3 \%$ & $2.8 \%$ & 6 & 6 & 5 & 5 \\
\hline Indonesia & 6,361 & 5,294 & 5,010 & 5,962 & $2.2 \%$ & $2.2 \%$ & $2.5 \%$ & $2.5 \%$ & 7 & 7 & 7 & 6 \\
\hline United Kingdom & 3,736 & 3,134 & 2,517 & 4,267 & $1.3 \%$ & $1.3 \%$ & $1.2 \%$ & $1.8 \%$ & 8 & 8 & 8 & 8 \\
\hline Brazil & 1,952 & 1,683 & 2,149 & 2,873 & $0.7 \%$ & $0.7 \%$ & $1.1 \%$ & $1.2 \%$ & 9 & 9 & 9 & 10 \\
\hline Canada & 1,807 & 1,506 & 1,275 & 2,482 & $0.6 \%$ & $0.6 \%$ & $0.6 \%$ & $1.0 \%$ & 10 & 10 & 12 & 11 \\
\hline Germany & 1,602 & 1,346 & 2,056 & 3,046 & $0.6 \%$ & $0.6 \%$ & $1.0 \%$ & $1.3 \%$ & 11 & 11 & 10 & 9 \\
\hline France & 1,271 & 1,084 & 1,670 & 2,232 & $0.4 \%$ & $0.4 \%$ & $0.8 \%$ & $0.9 \%$ & 12 & 12 & 11 & 12 \\
\hline Switzerland & 1,086 & 954 & 741 & 1,032 & $0.4 \%$ & $0.4 \%$ & $0.4 \%$ & $0.4 \%$ & 13 & 13 & 18 & 18 \\
\hline Netherlands & 941 & 785 & 771 & 1,147 & $0.3 \%$ & $0.3 \%$ & $0.4 \%$ & $0.5 \%$ & 14 & 14 & 17 & 15 \\
\hline Italy & 887 & 745 & 1,220 & 1,519 & $0.3 \%$ & $0.3 \%$ & $0.6 \%$ & $0.6 \%$ & 15 & 15 & 13 & 14 \\
\hline Turkey & 677 & 482 & 952 & 973 & $0.2 \%$ & $0.2 \%$ & $0.5 \%$ & $0.4 \%$ & 16 & 18 & 15 & 19 \\
\hline Spain & 674 & 566 & 851 & 1,131 & $0.2 \%$ & $0.2 \%$ & $0.4 \%$ & $0.5 \%$ & 17 & 17 & 16 & 16 \\
\hline Belgium & 672 & 569 & 640 & 638 & $0.2 \%$ & $0.2 \%$ & $0.3 \%$ & $0.3 \%$ & 18 & 16 & 19 & 20 \\
\hline Poland & 475 & 408 & 472 & 626 & $0.2 \%$ & $0.2 \%$ & $0.2 \%$ & $0.3 \%$ & 19 & 19 & 21 & 21 \\
\hline Mexico & 475 & 387 & 990 & 1,110 & $0.2 \%$ & $0.2 \%$ & $0.5 \%$ & $0.5 \%$ & 20 & 20 & 14 & 17 \\
\hline Sweden & 389 & 331 & 306 & 451 & $0.1 \%$ & $0.1 \%$ & $0.2 \%$ & $0.2 \%$ & 21 & 21 & 22 & 22 \\
\hline Russian Federation & 360 & 292 & 623 & 1,631 & $0.1 \%$ & $0.1 \%$ & $0.3 \%$ & $0.7 \%$ & 22 & 22 & 20 & 13 \\
\hline Denmark & 329 & 287 & 285 & 312 & $0.1 \%$ & $0.1 \%$ & $0.1 \%$ & $0.1 \%$ & 23 & 23 & 23 & 24 \\
\hline Ireland & 230 & 202 & 254 & 259 & $0.1 \%$ & $0.1 \%$ & $0.1 \%$ & $0.1 \%$ & 24 & 24 & 24 & 26 \\
\hline Norway & 205 & 170 & 188 & 328 & $0.1 \%$ & $0.1 \%$ & $0.1 \%$ & $0.1 \%$ & 25 & 25 & 27 & 23 \\
\hline Austria & 197 & 166 & 228 & 310 & $0.1 \%$ & $0.1 \%$ & $0.1 \%$ & $0.1 \%$ & 26 & 27 & 25 & 25 \\
\hline Bulgaria & 192 & 167 & 128 & 127 & $0.1 \%$ & $0.1 \%$ & $0.1 \%$ & $0.1 \%$ & 27 & 26 & 29 & 32 \\
\hline Czech Republic & 143 & 123 & 225 & 214 & $0.0 \%$ & $0.1 \%$ & $0.1 \%$ & $0.1 \%$ & 28 & 28 & 26 & 28 \\
\hline Finland & 108 & 88 & 147 & 198 & $0.0 \%$ & $0.0 \%$ & $0.1 \%$ & $0.1 \%$ & 29 & 29 & 28 & 30 \\
\hline Romania & 73 & 62 & 120 & 203 & $0.0 \%$ & $0.0 \%$ & $0.1 \%$ & $0.1 \%$ & 30 & 30 & 33 & 29 \\
\hline Luxembourg & 66 & 61 & 60 & 59 & $0.0 \%$ & $0.0 \%$ & $0.0 \%$ & $0.0 \%$ & 31 & 31 & 35 & 36 \\
\hline Slovak Republic & 47 & 40 & 122 & 116 & $0.0 \%$ & $0.0 \%$ & $0.1 \%$ & $0.0 \%$ & 32 & 32 & 31 & 33 \\
\hline Greece & 41 & 36 & 121 & 222 & $0.0 \%$ & $0.0 \%$ & $0.1 \%$ & $0.1 \%$ & 33 & 33 & 32 & 27 \\
\hline Slovenia & 34 & 28 & 41 & 60 & $0.0 \%$ & $0.0 \%$ & $0.0 \%$ & $0.0 \%$ & 34 & 34 & 36 & 35 \\
\hline Hungary & 25 & 21 & 126 & 110 & $0.0 \%$ & $0.0 \%$ & $0.1 \%$ & $0.0 \%$ & 35 & 35 & 30 & 34 \\
\hline Portugal & 22 & 18 & 117 & 157 & $0.0 \%$ & $0.0 \%$ & $0.1 \%$ & $0.1 \%$ & 36 & 36 & 34 & 31 \\
\hline Estonia & 9 & 8 & 20 & 29 & $0.0 \%$ & $0.0 \%$ & $0.0 \%$ & $0.0 \%$ & 37 & 37 & 39 & 41 \\
\hline Lithuania & 8 & 6 & 32 & 51 & $0.0 \%$ & $0.0 \%$ & $0.0 \%$ & $0.0 \%$ & 38 & 38 & 37 & 37 \\
\hline Croatia & 7 & 6 & 31 & 48 & $0.0 \%$ & $0.0 \%$ & $0.0 \%$ & $0.0 \%$ & 39 & 39 & 38 & 38 \\
\hline Latvia & 7 & 6 & 17 & 29 & $0.0 \%$ & $0.0 \%$ & $0.0 \%$ & $0.0 \%$ & 40 & 41 & 40 & 40 \\
\hline Cyprus & 7 & 6 & 13 & 31 & $0.0 \%$ & $0.0 \%$ & $0.0 \%$ & $0.0 \%$ & 41 & 40 & 41 & 39 \\
\hline Malta & 5 & 4 & 12 & 15 & $0.0 \%$ & $0.0 \%$ & $0.0 \%$ & $0.0 \%$ & 42 & 42 & 42 & 42 \\
\hline Rest of world & 93,652 & 78,402 & 55,886 & 75,384 & $32.6 \%$ & $32.6 \%$ & $27.7 \%$ & $31.6 \%$ & & & & \\
\hline Sum of bilaterals & 287,162 & 240,786 & 201,516 & 238,674 & $67 \%$ & $67 \%$ & $72 \%$ & $68 \%$ & & & & \\
\hline Aggregate & 287,162 & 240,468 & 201,516 & 238,674 & & & & & & & & \\
\hline
\end{tabular}

Note: Authors' calculations based on WIOD, 2016 release. 
Appendix Table A7 Bilateral exports by Brazil, 2014.

\begin{tabular}{|c|c|c|c|c|c|c|c|c|c|c|c|c|}
\hline & \multicolumn{4}{|c|}{ million US\$ } & \multicolumn{4}{|c|}{ Shares in total } & \multicolumn{4}{|c|}{ Ranking of countries } \\
\hline & GX & VAX-D & VAX-P & VAX-C & GX & VAX-D & VAX-P & VAX-C & GX & VAX-D & VAX-P & VAX-C \\
\hline China & 41,012 & 33,493 & 32,027 & 32,570 & $15.2 \%$ & $16.1 \%$ & $20.6 \%$ & $15.7 \%$ & 1 & 1 & 1 & 1 \\
\hline United States & 29,552 & 20,999 & 18,184 & 25,488 & $10.9 \%$ & $10.1 \%$ & $11.7 \%$ & $12.3 \%$ & 2 & 2 & 2 & 2 \\
\hline Japan & 9,054 & 7,084 & 6,202 & 8,508 & $3.4 \%$ & $3.4 \%$ & $4.0 \%$ & $4.1 \%$ & 3 & 3 & 3 & 3 \\
\hline Netherlands & 8,682 & 6,497 & 3,385 & 3,828 & $3.2 \%$ & $3.1 \%$ & $2.2 \%$ & $1.8 \%$ & 4 & 4 & 8 & 9 \\
\hline Germany & 7,025 & 5,359 & 4,938 & 6,015 & $2.6 \%$ & $2.6 \%$ & $3.2 \%$ & $2.9 \%$ & 5 & 6 & 5 & 4 \\
\hline India & 6,891 & 5,654 & 5,695 & 5,804 & $2.5 \%$ & $2.7 \%$ & $3.7 \%$ & $2.8 \%$ & 6 & 5 & 4 & 5 \\
\hline France & 4,871 & 3,879 & 3,771 & 4,737 & $1.8 \%$ & $1.9 \%$ & $2.4 \%$ & $2.3 \%$ & 7 & 7 & 6 & 7 \\
\hline Mexico & 4,856 & 3,388 & 2,419 & 3,193 & $1.8 \%$ & $1.6 \%$ & $1.6 \%$ & $1.5 \%$ & 8 & 10 & 12 & 13 \\
\hline United Kingdom & 4,779 & 3,840 & 3,047 & 5,107 & $1.8 \%$ & $1.8 \%$ & $2.0 \%$ & $2.5 \%$ & 9 & 8 & 9 & 6 \\
\hline South Korea & 4,341 & 3,416 & 3,407 & 3,471 & $1.6 \%$ & $1.6 \%$ & $2.2 \%$ & $1.7 \%$ & 10 & 9 & 7 & 10 \\
\hline Italy & 4,090 & 3,169 & 2,908 & 3,290 & $1.5 \%$ & $1.5 \%$ & $1.9 \%$ & $1.6 \%$ & 11 & 11 & 10 & 11 \\
\hline Russian Federation & 3,656 & 2,833 & 1,125 & 4,055 & $1.4 \%$ & $1.4 \%$ & $0.7 \%$ & $2.0 \%$ & 12 & 12 & 18 & 8 \\
\hline Canada & 3,495 & 2,600 & 2,300 & 2,949 & $1.3 \%$ & $1.2 \%$ & $1.5 \%$ & $1.4 \%$ & 13 & 15 & 14 & 14 \\
\hline Indonesia & 3,476 & 2,736 & 2,851 & 3,209 & $1.3 \%$ & $1.3 \%$ & $1.8 \%$ & $1.5 \%$ & 14 & 13 & 11 & 12 \\
\hline Spain & 3,302 & 2,601 & 2,418 & 2,632 & $1.2 \%$ & $1.2 \%$ & $1.6 \%$ & $1.3 \%$ & 15 & 14 & 13 & 15 \\
\hline Belgium & 3,121 & 2,408 & 1,296 & 2,013 & $1.2 \%$ & $1.2 \%$ & $0.8 \%$ & $1.0 \%$ & 16 & 16 & 17 & 16 \\
\hline Taiwan & 2,572 & 2,058 & 1,637 & 1,723 & $1.0 \%$ & $1.0 \%$ & $1.1 \%$ & $0.8 \%$ & 17 & 17 & 15 & 18 \\
\hline Norway & 1,708 & 1,362 & 855 & 1,095 & $0.6 \%$ & $0.7 \%$ & $0.5 \%$ & $0.5 \%$ & 18 & 18 & 20 & 20 \\
\hline Turkey & 1,677 & 1,280 & 1,509 & 1,504 & $0.6 \%$ & $0.6 \%$ & $1.0 \%$ & $0.7 \%$ & 19 & 19 & 16 & 19 \\
\hline Portugal & 1,185 & 940 & 720 & 849 & $0.4 \%$ & $0.5 \%$ & $0.5 \%$ & $0.4 \%$ & 20 & 21 & 21 & 21 \\
\hline Australia & 1,164 & 942 & 1,086 & 1,943 & $0.4 \%$ & $0.5 \%$ & $0.7 \%$ & $0.9 \%$ & 21 & 20 & 19 & 17 \\
\hline Denmark & 908 & 744 & 556 & 531 & $0.3 \%$ & $0.4 \%$ & $0.4 \%$ & $0.3 \%$ & 22 & 22 & 23 & 26 \\
\hline Ireland & 832 & 606 & 293 & 654 & $0.3 \%$ & $0.3 \%$ & $0.2 \%$ & $0.3 \%$ & 23 & 23 & 29 & 25 \\
\hline Sweden & 697 & 546 & 498 & 712 & $0.3 \%$ & $0.3 \%$ & $0.3 \%$ & $0.3 \%$ & 24 & 24 & 24 & 24 \\
\hline Poland & 646 & 510 & 589 & 760 & $0.2 \%$ & $0.2 \%$ & $0.4 \%$ & $0.4 \%$ & 25 & 25 & 22 & 22 \\
\hline Switzerland & 561 & 424 & 413 & 740 & $0.2 \%$ & $0.2 \%$ & $0.3 \%$ & $0.4 \%$ & 26 & 27 & 25 & 23 \\
\hline Finland & 560 & 435 & 362 & 397 & $0.2 \%$ & $0.2 \%$ & $0.2 \%$ & $0.2 \%$ & 27 & 26 & 26 & 28 \\
\hline Romania & 347 & 273 & 328 & 383 & $0.1 \%$ & $0.1 \%$ & $0.2 \%$ & $0.2 \%$ & 28 & 28 & 27 & 29 \\
\hline Austria & 341 & 265 & 319 & 491 & $0.1 \%$ & $0.1 \%$ & $0.2 \%$ & $0.2 \%$ & 29 & 29 & 28 & 27 \\
\hline Slovenia & 323 & 254 & 243 & 251 & $0.1 \%$ & $0.1 \%$ & $0.2 \%$ & $0.1 \%$ & 30 & 30 & 30 & 32 \\
\hline Bulgaria & 195 & 163 & 137 & 147 & $0.1 \%$ & $0.1 \%$ & $0.1 \%$ & $0.1 \%$ & 31 & 31 & 34 & 34 \\
\hline Hungary & 187 & 142 & 189 & 169 & $0.1 \%$ & $0.1 \%$ & $0.1 \%$ & $0.1 \%$ & 32 & 33 & 32 & 33 \\
\hline Greece & 183 & 148 & 202 & 330 & $0.1 \%$ & $0.1 \%$ & $0.1 \%$ & $0.2 \%$ & 33 & 32 & 31 & 30 \\
\hline Czech Republic & 143 & 110 & 182 & 271 & $0.1 \%$ & $0.1 \%$ & $0.1 \%$ & $0.1 \%$ & 34 & 34 & 33 & 31 \\
\hline Slovak Republic & 65 & 48 & 121 & 128 & $0.0 \%$ & $0.0 \%$ & $0.1 \%$ & $0.1 \%$ & 35 & 36 & 35 & 35 \\
\hline Croatia & 61 & 49 & 65 & 91 & $0.0 \%$ & $0.0 \%$ & $0.0 \%$ & $0.0 \%$ & 36 & 35 & 36 & 36 \\
\hline Estonia & 50 & 34 & 30 & 50 & $0.0 \%$ & $0.0 \%$ & $0.0 \%$ & $0.0 \%$ & 37 & 38 & 39 & 40 \\
\hline Lithuania & 46 & 36 & 50 & 88 & $0.0 \%$ & $0.0 \%$ & $0.0 \%$ & $0.0 \%$ & 38 & 37 & 38 & 37 \\
\hline Cyprus & 42 & 31 & 20 & 56 & $0.0 \%$ & $0.0 \%$ & $0.0 \%$ & $0.0 \%$ & 39 & 39 & 41 & 39 \\
\hline Latvia & 30 & 23 & 28 & 46 & $0.0 \%$ & $0.0 \%$ & $0.0 \%$ & $0.0 \%$ & 40 & 41 & 40 & 41 \\
\hline Luxembourg & 29 & 24 & 54 & 77 & $0.0 \%$ & $0.0 \%$ & $0.0 \%$ & $0.0 \%$ & 41 & 40 & 37 & 38 \\
\hline Malta & 22 & 15 & 13 & 26 & $0.0 \%$ & $0.0 \%$ & $0.0 \%$ & $0.0 \%$ & 42 & 42 & 42 & 42 \\
\hline Rest of world & 113,484 & 87,038 & 49,074 & 76,775 & $42.0 \%$ & $41.8 \%$ & $31.5 \%$ & $37.1 \%$ & & & & \\
\hline Sum of bilaterals & 270,263 & 208,455 & 155,545 & 207,157 & $58 \%$ & $58 \%$ & $68 \%$ & $63 \%$ & & & & \\
\hline Aggregate & 270,263 & 208,346 & 155,545 & 207,157 & & & & & & & & \\
\hline
\end{tabular}

Note: Authors' calculations based on WIOD, 2016 release. 